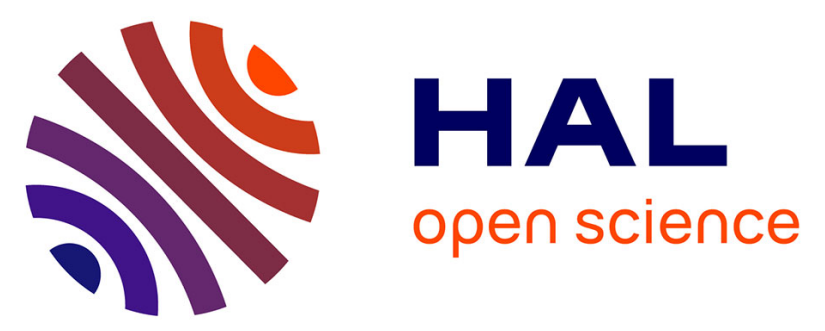

\title{
Treatment of hospital indoor air by a hybrid system of combined plasma with photocatalysis Case of trichloromethane
}

Tahar Zadi, Aymen Amin Assadi, Noureddine Nasrallah, Rachida Bouallouche, Phuong Nguyen Tri, Abdelkrim Bouzaza, Mohamed Miftah Azizi, Rachida Maachi, Dominique Wolbert

\section{To cite this version:}

Tahar Zadi, Aymen Amin Assadi, Noureddine Nasrallah, Rachida Bouallouche, Phuong Nguyen Tri, et al.. Treatment of hospital indoor air by a hybrid system of combined plasma with photocatalysis Case of trichloromethane. Chemical Engineering Journal, 2018, 349, pp.276-286. 10.1016/j.cej.2018.05.073 . hal-01863976

\section{HAL Id: hal-01863976}

\section{https://hal-univ-rennes1.archives-ouvertes.fr/hal-01863976}

Submitted on 3 Sep 2018

HAL is a multi-disciplinary open access archive for the deposit and dissemination of scientific research documents, whether they are published or not. The documents may come from teaching and research institutions in France or abroad, or from public or private research centers.
L'archive ouverte pluridisciplinaire HAL, est destinée au dépôt et à la diffusion de documents scientifiques de niveau recherche, publiés ou non, émanant des établissements d'enseignement et de recherche français ou étrangers, des laboratoires publics ou privés. 


\section{Treatment of hospital indoor air by a hybrid system of combined plasma with photocatalysis: case of trichloromethane}

Tahar Zadi ${ }^{\mathrm{a}, \mathrm{b}}$, Aymen Amin Assadi ${ }^{\mathrm{b}^{*}}$, Noureddine Nasrallah ${ }^{\mathrm{a}}$, Rachida Bouallouche $^{\mathrm{a}}$, Phuong Nguyen TRI $^{c, d}$, Abdelkrim Bouzaza $^{b}$, Mohamed Miftah Azizi $^{e}$, Rachida Maachi $^{\mathrm{a}}$, Dominique Wolbert ${ }^{\mathrm{b}}$

a'Laboratory of Engineering Reaction, Faculty of Engineering Mechanic and Engineering Processus (USTHB), BP 32, Algiers, Algeria.

bUMR6226 CNRS,ENSCR-11, allée de Beaulieu,CS508307-35708Rennes,France.

${ }^{\mathrm{c} D e p a r t m e n t ~ o f ~ C h e m i s t r y, ~ P a v i l l o n ~ J .-A r m a n d-B o m b a r d i e r, ~ M o n t r e a l ~ U n i v e r s i t y, ~ M o n t r e ́ a l, ~ Q C ~}$

${ }^{\mathrm{d} D e p a r t m e n t}$ of Civil Engineering, ETS, Montréal, Canada

${ }^{\mathrm{e}}$ Faculty of Science and Arts in Qilwah-65941-Albaha University-Saudi Arabia

\section{(Aymen.assadi@ensc-rennes.fr)}

\section{ABSTRACT}

The purpose of this study is to evaluate the efficiency of non-thermal plasma and heterogeneous photocatalysis processes for indoor air treatment using cylindrical continuous reactor at pilot scale and high flow rates. Trichloromethane $\left(\mathrm{CHCl}_{3}\right)$ also called chloroform was chosen as a model pollutant representing hospital indoor air. This pollutant is considered as carcinogenic, mutagenic and reprotoxic agent. The effect of several parameters such as inlet pollutant concentrations (25-300 mg $\mathrm{m}^{-3}$ ), flow rates $\left(2\right.$ to $8 \mathrm{~m}^{3} \mathrm{~h}^{-1}$ ), relative humidity of the effluent $(5,30,50$ and $90 \%)$ as well as input of the plasma discharge (9 to $21 \mathrm{kV}$ ) on the photodegradation of trichloromethane is investigated.

Our findings show that the increase of flow rate leads to a reduction of degradation efficiency, while the humidity promotes the degradation in the case of photocatalysis process due to the formation of $\mathrm{OH}^{*}$ radicals.

Moreover, the addition of a photocatalyst under UV radiation in the discharge zone enhances the reduction of ozone and CO gases compared to plasma process alone.

The combination of plasma DBD and photocatalysis enhances the removal efficiency with a synergetic effect, leading to removal efficiency higher than $10 \%$ if we consider the sum of the contribution of each process separately. 
Keywords: plasma DBD/photocatalysis process, cylindrical reactor, Chloroform removal, synergetic effect.

\section{INTRODUCTION}

Emissions of volatile organic compounds (VOCs) into atmosphere are detrimental to both human health and the global environment [1]. In recent years, plasma technology has been applied to remove VOCs and chlorinated volatile organic compounds (CVOCs) $[2,3,4]$. The dielectric barrier discharge reactor (DBD) is often used in non-thermal plasma (NTP) technology. Several investigations showed that DBD reactors appeared to be most interesting from an economic point of view and they are recognized to be relevant for VOCs removal [5,6]. Additionally, a combination of photocatalytic process with discharge plasma leads to an improvement in the treatment efficiency of VOCs [5].

Titanium dioxide $\left(\mathrm{TiO}_{2}\right)$, the most used semiconductor, is activated by photons provided by an ultra violet (UV) radiation $[7,8,9]$. Many studies have shown $[8,9,10]$ that the photocatalytic process $\left(\mathrm{TiO}_{2}+\mathrm{UV}\right)$ is an promising way for the treatment of air polluted by VOCs. Indeed, photocatalysts are semiconductors activated by photons which create electron-hole pairs, inducing oxidation or reduction reactions at the surface of the material with adsorbed molecules $[8,9] . \mathrm{TiO}_{2}$ activated by UV radiation is one of the most efficient photocatalysts for VOC treatment. No ozone and no CO were produced with process. Moreover, other researchers have studied the combination of NTP with $\mathrm{TiO}_{2}+\mathrm{UV}$ for the removal of VOC at scale laboratory [11,12]. It is now well established that combined process improves the removal of pollutants [2]. Several studies have demonstrated a synergistic effect between NTP and $\mathrm{TiO}_{2}+\mathrm{UV}$ processes $[4,13,14,15]$.

The major drawback of the NTP removal process is the formation of by-products like $\mathrm{CO}_{\mathrm{x}}$, ozone, $\mathrm{NO}_{\mathrm{x}}$, which can be more harmful than the target VOC itself. Various researches deal to overcome this limit by a combination of NTP with heterogeneous catalysis $[16,17,18,19]$.

In this work, Chloroform has been chosen as a model pollutant of a CVOC. This pollutant is the main hospital indoor air pollutant and is considered as carcinogenic, mutagenic and reprotoxic agent $[21,22]$.

Moreover, the novelty of this study is to investigate the synergetic effect between non-thermal plasma and heterogeneous photocatalysis processes during the chlorinated compound in the indoor air with a 
significant influence of the coupling impact on ozone and $\mathrm{CO}$ through various operating parameters. Moreover, the effect of the new configuration of inner electrode has been investigated by changing from inner electrode to spiral electrode $[11,14,18]$ to stainless steel grid electrode..

\section{EXPERIMENTAL}

\section{Pilot system and setup details}

The experimental works were carried out on a cylindrical reactor which has a coaxial structure and $1500 \mathrm{~mm}$ in length. It consists of two concentric tubes made of Pyrex glass (Fig.1) with equal internal diameters of $58 \mathrm{~mm}$ for internal tube and $67 \mathrm{~mm}$ for external tube. The internal tube contains the UV lamps (Philips CLEO performance 80W/10 model). The UV intensity, which is measured by a UV radiometer (VLX-3W equipped with a sensor CX 365, ALYS Technologies, Switzerland) at the photocatalyst surface, is equal to $20 \pm 3 \mathrm{~W} \cdot \mathrm{m}^{-2}$. The external tube is divided into four sections, the length of the reactive zone is $800 \mathrm{~mm}$, and the surface of the catalyst media is $0.20 \mathrm{~m}^{2}$. The catalyst used, Glass Fiber Tissue (GFT), was supplied by Ahlstrom Research and Services [24]. It is containing colloidal silica, percentage of titanium dioxide nanoparticles, percentage of manganese dioxide nanoparticles and inorganic fibers. In fact, titanium dioxide or manganese dioxide has been deposited on inorganic fibers by impregnation using an industrial-size press. A dry mixture of $50 \mathrm{wt} \%$ colloidal silica and different wt\% of titanium dioxide nanoparticles (PC500 Millennium) and manganese dioxide is suspended in pure water. In order to ensure the deposition of $13 \mathrm{~g} / \mathrm{m}^{2}$ of dry $\mathrm{TiO}_{2}$ on fiber support, the suspension is composed of $40 \%$ of dry powder and $60 \%$ of pure water. The press is employed to impregnate fibers with the suspension; then they are dried. According to BET method, specific surface area is measured and is equal to $20.6 \mathrm{~m}^{2} \cdot \mathrm{g}^{-1}$ of $\mathrm{TiO}_{2}$. The repetitive use of this GFTTiO2 photocatalyst up to the 5th cycle leading to butyraldehyde degradation was done in our previous works. No loss of activity was detected by the photocatalyst during its repetitive recycling. [18]

The gaseous effluent flows between the inner wall of the outer tube and the external wall of the inner tube.

Fig.1. Drawing of the cylindrical photo reactor (a) and the cross-section (b). 
To generate the plasma on catalytic surface (Fig.2), a reactor on discharge of dielectric barrier (DBD) at room temperature and atmospheric pressure is used. The cylindrical reactor is covered by copper electrode $(0.5 \mathrm{~mm}$ thickness) rolled up and stuck on the external wall of the tube, and is connected to the ground through a $2.5 \mathrm{nF}$ capacity to collect the charges. The internal electrode (high voltage electrode) is established of a rolling-up of two Railings of metal spread in stainless steel square stitch of $2 \mathrm{~mm}$ of thickness and $800 \mathrm{~mm}$ length in narrow contact with the internal wall of the outside tube of the reactor. The latter plays the role of the dielectric barrier. This barrier is connected to an amplifier (TREK model PD06035), which allows to amplify the signal of the generator 3000 times and thus to increase the voltage up to $21 \mathrm{kV}$ coupled with a signal generator (BFI Optilas reference DS 335/1) which allows to deliver a sinusoidal signal having a range of voltage of $50 \mathrm{mV}$ to $7 \mathrm{~V}$. Detailed description of the pilot system is shown in (Fig.2). The DBD surfacic plasma is generated on the surface of the catalyst installed in the annular space of the reactor. The construction of this reactor and the stainless steel grid allowed having uniform plasma. Likewise the grid ensures the fixation of the catalyst against the internal wall of the reactor. Moreover, the cylindrical geometry ensures a uniform UV radiation of the catalyst.

Two high voltage probes (NORTH STAR), connected with oscilloscope (LeCroy Wave Surfer 24 digital $\mathrm{Xs}-\mathrm{A}$ ) to visualize the variations of signal (tension and current) as a function of time, this apparatus allows to measure the voltages across the reactor and coils of condensers.

Fig.2. General schematic view of the circuit electric of the photocatalysis and plasma DBD in an annular reactor.

The air flow is controlled by a flow meter (Bronkhorst In-Flow type E-700) coupled to a precision valve. The flow range can vary from 2 to $8 \mathrm{~m}^{3} \mathrm{~h}^{-1}$.

The main air flow is generated by two ways. When the relative humidity $(\mathrm{RH})$ is low $(\mathrm{RH}<5 \%)$, we use the internal compressed air network. At higher $\mathrm{RH}$, a centrifugal pump is used with the ambient air. A fraction of the inlet air passes counter-currently through a column filled with glass Raschig rings with water is used to control the $\mathrm{RH}(25$ to $90 \%)$.

The pollutant, air-Chloroform (VWR BDH Prolabo-99.4\%), is directly and continuously injected into the inlet air with the aid of a syringe / syringe drive system through a septum perpendicularly to the gas stream. To improve the pollutant evaporation, a heating system is used for covering the injection zone. 
Fig.3. General schematic view of the pilot system: photocatalysis and plasma DBD.

\section{Apparatus and analysis}

Gas Chromatography with flame ionization detection (GC-FID, GC 9000 series, Thermo Focus, USA) is used to evaluate the inlet-outlet chloroform concentrations. The capillary column used is Chrompact FFAP-CB (25 m length and $0.32 \mathrm{~mm}$ external diameter), and Nitrogen $\left(\mathrm{N}_{2}\right)$ gas is the mobile phase.

The injections are made manually from the samples taken in the reactors with syringes of $500 \mu \mathrm{L}$. The concentration of carbon monoxide (CO) at the reactor outlet is measured by CO/NOx ZRE gas device commercialized by Fuji Electric S.A.S.

The ozone produced by the plasma treatment is analyzed by colorimetric titration method after bubbling [25]. Thus, at the outlet of the plasma reactor, a constant flow rate $\left(130 \mathrm{~L} \mathrm{~h}^{-1}\right)$ of the gas stream containing $\mathrm{O}_{3}$ bubbles in a solution of $\mathrm{KI}$ at $10^{-2} \mathrm{M}$. The presence of $\mathrm{O}_{3}$ leads to the oxidation of $I^{-}$to $I_{2}$, giving the solution a yellow color. $\mathrm{I}_{2}$ is then titrated until discoloration with a solution of $\mathrm{Na}_{2} \mathrm{~S}_{2} \mathrm{O}_{3}$ at $10^{-3} \mathrm{M}$. This titration is carried out in an acid medium, after adding a few drops of $\mathrm{HCl}$ solution.

The reactions which will take place during bubbling and dosing are:

$$
\begin{aligned}
& \mathrm{O}_{3}+2 \mathrm{I}^{-} \rightarrow \mathrm{I}_{2}+\mathrm{O}_{2}+\mathrm{O}^{-}+\mathrm{e}^{-} \\
& \mathrm{I}_{2}+2 \mathrm{~S}_{2} \mathrm{O}_{3}^{-2} \rightarrow 2 \mathrm{I}^{-}+\mathrm{S}_{4} \mathrm{O}_{6}^{-2}
\end{aligned}
$$

\section{RESULTS AND DISCUSSION}

The continuous removal of the Chloroform by different processes (plasma, photocatalysis and combined system) is studied by examining in various operating parameters such as pollutant concentration, flow rate, relative humidity, and injected energy. For each test, the degradation kinetic of chloroform and the by-products elimination (as CO and ozone) are estimated.

Then irradiation and/or electric discharge was turned on, removal begins. The input and output concentrations are measured until the steady-state is reached. At the end of the experiment, the reactor was cleaned by a current of unpolluted air during at least two hours. 
In order to monitor the performance of the process, some operational conditions/parameters are studied:

$$
\text { Specific energy }\left(\mathrm{SE} ; \mathrm{J} . \mathrm{L}^{-1}\right)=\left(\mathrm{P}(\mathrm{W}) / \mathrm{Q}\left(\mathrm{m}^{3} \cdot \mathrm{s}^{-1}\right)\right) / 1000 \quad(\text { Eq.2) }
$$

where $\mathrm{P}$ is input power adjusted by changing the applied voltage $\left(\mathrm{U}_{\mathrm{a}}\right)$ at frequency $=50 \mathrm{~Hz}$ and $\mathrm{Q}$ is the flowrate.

The overall degradation rate is one of the criteria used for evaluating the performance of VOC's elimination.

It is defined as Chloroform Removal Efficiency (CRE):

$$
\operatorname{CRE}(\%)=\left(\left[\mathrm{CHCl}_{3}\right]_{\text {inlet }}-\left[\mathrm{CHCl}_{3}\right]_{\text {outlet }}\right) \times 100 /\left[\mathrm{CHCl}_{3}\right]_{\text {inlet }}
$$

Other expressions can also be used to evaluate the process performance:

The Rate of Synergy (RS) calculated by the following expression:

$$
\mathrm{RS}=\mathrm{CRE}_{\text {combined process }} /\left(\mathrm{CR} \mathrm{E}_{\text {plasma }}+\mathrm{CR} \mathrm{E}_{\text {photocatalysis }}\right)
$$

The Intermediate By-products Efficiency (IBE) is calculated with:

$$
\begin{aligned}
& \mathrm{IBE}_{\mathrm{ozone}}=\left([\text { ozone }]_{\text {plasma }}-[\text { ozone }]_{\text {combined process }}\right) \times 100 /[\text { ozone }]_{\text {plasma }} \\
& \mathrm{IBE}_{\mathrm{CO}}=\left([\mathrm{CO}]_{\text {plasma }}-[\mathrm{CO}]_{\text {combined process }}\right) \times 100 /[\mathrm{CO}]_{\text {plasma }}
\end{aligned}
$$

Where $\left[\mathrm{CHCl}_{3}\right]$ is the concentration of chloroform in $\mathrm{mg} \mathrm{m}^{-3}, \mathrm{Q}$ is the gas flow rate in $\mathrm{m}^{3} \mathrm{~h}^{-1}$, [ozone] and $[\mathrm{CO}]$ is the concentration in ppm of ozone and CO respectively.

\subsection{Effect of flow rates and inlet concentrations on chloroform degradation}

Removal of chloroform was investigated in the annular reactor under various inlet concentrations and flow rates. The inlet chloroform concentration varies from 25 to $300 \mathrm{mg} \cdot \mathrm{m}^{-3}$, and the flow rates of effluent were in the interval of $2-8 \mathrm{~m}^{3} \cdot \mathrm{h}^{-1}$.

\subsubsection{Photocatalysis alone}


(Fig.4) shows the influence of gas flow rates and inlet concentrations on the removal efficiency of chloroform. The corresponding residence times in the annular plug-flow reactor for gas flow rate of 2 , 4,6 and $8 \mathrm{~m}^{3} \cdot \mathrm{h}^{-1}$ are $2.4,1.2,0.8$ and $0.6 \mathrm{~s}$ respectively.

As expected, this behavior is in line with those reported in the literature $[10,26]$. For a given flow rate, it shows that the removal capacity first increases proportionally with the inlet concentration (Fig.4). At low inlet concentration, the degradation fits as a first-order kinetic reaction. This is due to the availability of the photocatalytic sites at this concentration range. At higher pollutant concentration, the degradation rate tend to a limit $[10,26]$.

On the other hand, at different flow rates, it can be seen that the flow rate has a positive influence on the rate of degradation, independent on the input charge. The overall kinetics reaction would thus be completely controlled by the mass transfer step. In fact, two phenomena may occur when the flux increases at a constant load: i) the improvement of the mass transfer and ii) the reduction of the residence time, as described recently [9].

Fig.4. Influence of gas flow rates and inlet concentrations on the removal efficiency of chloroform by photocatalysis alone:

$$
\mathrm{RH}=50 \%, \mathrm{~T}=20^{\circ} \mathrm{C}, \mathrm{I}=20 \mathrm{~W} \cdot \mathrm{m}^{-2} \text {. }
$$

\subsubsection{The plasma $D B D$ alone}

For the plasma tests, the UV lamps were turned off. Four voltage values were chosen to follow this oxidation process.

(Fig.5) presents the oxidation of chloroform at two different initial concentrations by non-thermal plasma at various injected voltages and at a constant flow rate of $2 \mathrm{~m}^{3} \cdot \mathrm{h}^{-1}$.

It is worth mentioning that whatever the value of the inlet concentration, the increase of injected voltage leads to an increase of the CRE. By electron impact, the plasma produces radicals $\mathrm{O}^{\circ}, \mathrm{HO}^{\circ}$ $[14,15]$. When the injected voltage is increased, more radicals are produced which react more or less directly with chloroform.

The CRE decreases with increasing inlet concentration; the CRE was reduced two times when the inlet concentration increases from 25 to $100 \mathrm{mg} \mathrm{m}^{-3}$. 
This is due the lack of electrons and reactive species (like $\mathrm{O}^{\circ}$ and $\mathrm{OH}^{\circ}$ ) when the inlet pollutant concentration increases.

Fig 5: Influence of gas flow rates and inlet concentrations on the removal capacity of chloroform by photocatalysis alone:

$$
\mathrm{RH}=50 \%, \mathrm{~T}=20^{\circ} \mathrm{C}, \mathrm{I}=20 \mathrm{~W} \mathrm{~m}^{-2} \text {. }
$$

The effect of the residence time with a plasma DBD reactor was also studied. For an inlet concentration of $100 \mathrm{mg} \mathrm{m}^{-3}$, the effect of injected voltages at different flow rates on the CRE was followed (Fig.6).

At the same time, the increase of flow rates leads to a reduction of the CRE. This effect is similar to that observed for photocatalytic process alone.

Express the molecular diffusivity $\left(D_{m}\right)$ of a two-component system as follows [27]:

$$
D_{m}=\frac{1.43 \times 10^{-3} \times T^{1.75}}{P\left[\left(\sum v\right)_{A}^{(1 / 3)}+\left(\sum v\right)_{B}^{(1 / 3)}\right]^{2}}\left(\frac{1}{M_{A}}+\frac{1}{M_{B}}\right)^{0.5}
$$

This expression (7) makes it possible to calculate the coefficient of diffusivity in air of chloroform $\left(D_{m}=\right.$ $0.01977 \mathrm{~cm}^{2} \cdot \mathrm{s}^{-1}$ ). The internal mass-transfer step can be neglected because $\mathrm{TiO}_{2}$ is deposited on the substrate surface where the reaction occurs.

The external mass-transfer coefficient, $\mathrm{k}_{\mathrm{m}}$ is estimated using a semi-empirical correlation (Eq.8) developed in annular reactors for laminar flow [28]:

$$
\mathrm{Sh}=1.029 \times \mathrm{Sc}^{0.33} \times \mathrm{Re}^{0.55} \times\left(\frac{\text { Ltot }}{\mathrm{d}}\right)^{-0.472}
$$

Then the mass transfer coefficients are calculated and shown in Table 1.

Table 1: Values of the residence times, Reynolds number and mass transfer coefficients in the annular reactor:

\begin{tabular}{|c|c|c|c|}
\hline Flow rate $\left(\mathbf{Q}, \mathbf{~}^{3} \mathbf{h}^{-1}\right)$ & Residence times $(\mathbf{s})$ & Reynolds number & $\begin{array}{c}\text { Mass transfer coefficient of } \\
\text { Chloroform }\left(\boldsymbol{k}_{\mathrm{m}} \times \mathbf{~ 1 0}^{\mathbf{5}}, \mathbf{~ m ~ s}^{-\mathbf{1}}\right)\end{array}$ \\
\hline 2 & 2.4 & 380 & 0.76 \\
\hline 4 & 1.2 & 760 & 1.12 \\
\hline
\end{tabular}




\begin{tabular}{|c|c|c|c|}
\hline 6 & 0.8 & 1140 & 1.41 \\
\hline 10 & 0.6 & 1900 & 1.9 \\
\hline
\end{tabular}

The increase in flow rate decreases the residence time and increases the mass transfer coefficient due to negative effect of flow rate, leading to an unfavorable or favorable effect. It seems that the reaction between the radicals and the chloroform does not take place in this condition.

We note also that whatever the flow rate, the increase of the injected voltage improves the conversion rate.

Fig.6. Influence of applied voltages at different flow rates on the CRE in plasma alone:

$$
\left[\mathrm{CHCl}_{3}\right]=100 \mathrm{mg} \mathrm{m}^{-3}, \mathrm{HR}=50 \%, \mathrm{~T}=20^{\circ} \mathrm{C}
$$

\subsection{3. $\mathrm{DBD} / \mathrm{TiO}_{2}+\mathrm{UV}$ plasma coupling}

As for each process mentioned above, the influence of operating parameters on process performance will be studied for the combined system plasma and photocatalysis. Firstly, the DBD treatment and $\mathrm{TiO}_{2}+\mathrm{UV}$ photocatalysis process can be subdivided into six phases (i) transfer of gaseous reactants (Chloroform and oxygen) to the discharge zone (ii) oxidation reaction on the discharge zone (iii) transfer of gaseous reactants and byproducts to the solid phase (iv) oxidation reaction in solid phase (v) desorption of gaseous photocatalytic reaction products and byproducts (vi) diffusion of products to bulk phase.

\subsubsection{Removal efficiency}

The same values of injected voltage and UV intensity are maintained during these experiments in order to compare the results between the three processes: photocatalysis, DBD plasma, and $\mathrm{DBD} /$ photocatalysis. The evolution of the chloroform removal as a function of injected voltage is similar to that observed for the DBD plasma alone (Fig.7).

Quite logically, the conversion rate increases with the injected voltage. The elimination is complete for $\left[\mathrm{CHCl}_{3}\right]=100 \mathrm{mg} \mathrm{m}^{-3}$ with a flow rate of $2 \mathrm{~m}^{3} \mathrm{~h}^{-1}$ from $15 \mathrm{kV}$. With the coupling process, we also find an improvement in the CRE, which is higher than the sum of those in plasma alone and in photocatalysis. 
Fig.7. Influence of injected voltages at different flow rates on the CRE with plasma DBD/TiO ${ }_{2}+\mathrm{UV}$ :

$$
\left[\mathrm{CHCl}_{3}\right]=100 \mathrm{mg} \mathrm{m}^{-3}, \mathrm{RH}=50 \%, \mathrm{l}=20 \mathrm{~W} \mathrm{~m}^{-2}, \mathrm{~T}=20^{\circ} \mathrm{C} .
$$

\subsubsection{Synergetic effect}

Figure 8 demonstrates the variation of RS at two different parameters, various flow rates at $15 \mathrm{kV}$ and applied voltages at $2 \mathrm{~m}^{3} \mathrm{~h}^{-1}$ using three processes at a constant concentration of chloroform of $100 \mathrm{mg}$ $\mathrm{m}^{-3}$ and $\mathrm{RH}=50 \%$.

At can be seen from this figure that, the RS of the combined system is usually higher compared to each process considered separately. Moreover, we note the existence of a synergy due to the process combination. RS is mainly higher (about 1.17-1.33) than the sum of the CRE for each separated process whatever the flow is.

An increase of the injected voltage leads to an increase in RS for the combined process. This trend is still observed with different input voltages.

The RS by coupling plasma DBD and photocatalysis was 1.16-1.18 higher than the sum of the removals recorded at the same conditions for plasma DBD alone and photo-catalysis alone. Therefore, a synergistic effect occurs on the surface of the GFT when coupling plasma and photocatalytic processes.

This trend was the same for all flow rates and voltage values applied in the reactor. This is due to the role of neutrals (including molecules, radicals, metastable species and atoms), ions, electrons, photons and electric fields, on the improvement of plasma-catalyst surface interactions in terms of surface chemical reactions and the improvement of mass transfer [11]. Similar observations have been found in the literature for various VOCs $[11,14,15,29,30]$.

The synergistic effect observed on the photocatalytic surface can be attributed to:

Non-thermal plasma involving different processes since plasma produces many species such as high-voltage electrons, excited molecules such oxygen atomic $\left(\mathrm{O}^{\circ}\right)$ in dry air and radicals $\left(\mathrm{O}^{\circ}, \mathrm{HO}^{\circ}, \mathrm{O}_{2}{ }^{\circ}, \mathrm{O}_{3}, \mathrm{NO}_{x}\right.$, etc. $)$ in wet air. These species can interact with chloroform molecules leading to its degradation $[13,14]$. 
$>$ Plasma promoting the desorption of byproducts attached at the $\mathrm{TiO}_{2}$ surface leads to its mineralization. In fact, Abou Sadou et al. showed a significant regeneration that has been occurred by combining photocatalysis and nonthermal plasma. Indeed, the surface atomic percentage (XPS) on the catalyst surface at time zero, after the catalyst poisoning and after the plasma treatment were studied and results give the evidence for surface regeneration with plasma. Thus, it has also been demonstrated that DBD-plasma may effectively regenerate poisoned catalysts. This trend can explain the synergetic effect during the sulfur pollutant degradation time [18].

> Activation of the $\mathrm{TiO}_{2}$ due to Plasma can induce by creating hole/electron pairs through ion bombardment $[5,11,31]$.

D Enhancing of mass transfer between plasma and catalysis zones. In fact, Assadi et al. supposed that the presence of the turbulences generated by plasma on the photocatalytic medium can enhance the mass transfer. Moreover they found that an increase of four times the value of mass transfer coefficient and argued that the model is able to predict the synergetic effect [35].

Fig.8. Variation of $\mathrm{RS}$ with flow rate (at $\mathrm{V}=15 \mathrm{kV}$ ) and applied voltage (at $\mathrm{Q}=2 \mathrm{~m}^{3} \mathrm{~h}^{-1}$ ) using three processes:

$\left[\mathrm{CHCl}_{3}\right]=100 \mathrm{mg} \mathrm{m}^{-3}, \mathrm{RH}=50 \%, \mathrm{l}=20 \mathrm{~W} \mathrm{~m}^{2}, \mathrm{~T}=20^{\circ} \mathrm{C}$.

\subsubsection{Intermediate by-products}

\subsection{Injected voltages effect}

Firstly, we note that no ozone and CO was produced by photocatalysis and/or photolysis. Moreover, with our system, the amount of NOx is lower than $1.5 \mathrm{ppm}$ in each operating parameter tested.

Figure 9 shows the effect of the initial concentration of chloroform on the formation of ozone at the outlet of the plasma reactor DBD at different voltages. It can be seen that, for an increase of the initial concentration, the ozone concentration formed at the outlet of the reactor decreases. Ozone is formed by the recombination reactions of atomic oxygen. Indeed, by electron impact, plasma produces radicals and active species. For example, atomic oxygen is formed by dissociation of $\mathrm{O}_{2}$ and then is consumed over a few hundred microseconds by combining and producing ozone [32,33].

The following reaction shows the formation of ozone $[34,35,36]$ : 


$$
\mathrm{O}^{\bullet}+\mathrm{O}_{2}+\mathrm{M} \rightarrow \mathrm{O}_{3}+\mathrm{M} \quad(\text { Eq. 9) }
$$

where $\mathrm{M}$ may be molecular oxygen.

Atomic oxygen contributes to the removal of chloroform, its concentration decreases, reducing the probability of recombination with $\mathrm{O}_{2}$ to form ozone. That could be explained by the fact that more electrons and reactive species (such as $0^{\circ}$ ) were formed and then leads to ozone production (Eqs. 9 and 10) $[37,38]$.

$$
\mathrm{e}^{-}+\mathrm{O}_{2} \rightarrow \mathrm{e}^{-}+\mathrm{O}^{\cdot}+\mathrm{O}^{\bullet}
$$

Fig.10 shows IBE variation for ozone and CO at different applied voltages for an input concentration of100 mg. $\mathrm{m}^{-3}$.

From figures 9 and 10, the concentration of ozone increases slowly with the injected voltages into the discharge zone, that can be linked to the removal efficiency of by-product for ozone decreases from 46 to $32 \%$ because of the accumulation and/or excess of ozone concentration in the reactor.

Fig.9. Influence of applied voltages at different inlet concentrations on ozone formation with plasma/TiO ${ }_{2}+U V$ :

$$
\mathrm{HR}=50 \%, \mathrm{~T}=20^{\circ} \mathrm{C}
$$

The results show that the IBE of the $\mathrm{CO}$ decreases with the combined process. The presence of the catalyst may play an important role on the reduction of the $\mathrm{CO}$ formation. For the decomposition of chloroform, these results imply that the IBE of the CO decreases as the amount of chloroform decomposition increases. O-mediated species are thought to contain $\mathrm{CO}$ more readily than those without $\mathrm{O}$.

When $\mathrm{TiO}_{2}$ is incorporated in a DBD reactor, the IBE of the CO for chloroform could reach to $50 \%$ at an applied voltage of $9 \mathrm{kV}$. Furthermore, the $\mathrm{TiO}_{2}$ catalyst could effectively prevent the formation of residues in the chloroform decomposition. The results shown in Fig.10 imply that the $\mathrm{TiO}_{2}$ in the plasma reactor has a catalytic activity to oxidize the intermediate hydrocarbon by-products such as CO and ozone.

\subsection{Effect of flow rates}


Fig.11 shows variation the IBE of ozone and $\mathrm{CO}$ with different flow rates. The reduction of the residence time leads to a decrease of $\mathrm{CO}$ and the IBE of $\mathrm{CO}$ remains low even at high voltages and flow rates.

Reduction of the residence time has an inverse effect on the IBE of CO. This allows us to proven that the reactive species do not have sufficient time to oxidize the by-products generated during the oxidation of pollutant. The flow is inversely proportional to the conversion rate due to the reduction of the residence time in the reactor. By reducing the residence times, the pollutant molecules have less time to react. This is despite the fact that an increase in the flow rate results in a decrease of the resistance to the transfer of material. This result is similar to that observed in a continuous reactor $[39,40,41]$.

Regarding our findings for the combined process, ozone formation is usually less than that for plasma treatment.

The plasma DBD/TiO ${ }_{2}+\mathrm{UV}$ coupling, ozone removal is between 46 and $33 \%$ at $6 \mathrm{~m}^{3} \mathrm{~h}^{-1}$. This reduction of $\mathrm{O}_{3}$ formation is due to the activation of $\mathrm{TiO}_{2}$ by $\mathrm{UV}$ radiation, which leads to following reactions [14]:

$$
\mathrm{O}_{3}+\mathrm{e}^{-} \rightarrow 0^{\bullet-}+\mathrm{O}_{2} \text { (Eq.11) }
$$

Or

$$
\mathrm{O}_{3}+\mathrm{hv}(\lambda<310 \mathrm{~nm}) \rightarrow \mathrm{O}_{2}+\mathrm{O}^{\bullet}(\text { Eq.12) }
$$

The $\mathrm{DBD} / \mathrm{TiO}_{2}+\mathrm{UV}$ plasma process therefore reduces slightly the production of ozone compared to that obtained during manipulations with plasma alone. In fact, the interaction between ozone and catalyst should be investigated in details.

Fig.10. Variation the IBE of ozone and CO with applied voltage: $\left[\mathrm{CHCl}_{3}\right]=100 \mathrm{mg} \mathrm{m}^{-3}, \mathrm{Q}=6 \mathrm{~m}^{3} \mathrm{~h}^{-1}, \mathrm{RH}=50 \%, \mathrm{I}=20 \mathrm{~W} \mathrm{~m}^{-2}, \mathrm{~T}=20^{\circ} \mathrm{C}$

Fig.11. Variation the IBE of ozone and $\mathrm{CO}$ with flow rate:

$\left[\mathrm{CHCl}_{3}\right]=100 \mathrm{mg} \mathrm{m}^{-3}, \mathrm{~V}=18 \mathrm{kV}, \mathrm{RH}=50 \%, \mathrm{l}=20 \mathrm{~W} \mathrm{~m}^{-2}, \mathrm{~T}=20^{\circ} \mathrm{C}$.

\subsection{Effect of the relative humidity}


The relative humidity $(\mathrm{RH})$ of air can play an important role on the process performance and thus, this parameter has to take into account on CRE and by-products formation.

\subsubsection{Photocatalytic process}

The photocatalytic degradation is usually affected by water vapor. In most cases, the total absence of water is fatal to photocatalysis because this directly affects the quantity of hydroxyl radicals formed. On the other hand, high $\mathrm{RH}$ value can negatively affect the process due to a competitive effect between water and pollutant [42].

Four relative humidity values $(\mathrm{RH})$ of the air are set ranging from 5 , to $90 \%$ Figure12 indicates that the water molecules have a significant effect on the conversion rate with a maximum regardless of the initial concentration of chloroform. In fact, at low $\mathrm{RH}$, a slight increase of $\mathrm{RH}$ enhances the production of $\mathrm{OH}^{\circ}[43]$ and thus the conversion rate. For example, for an inlet concentration of $25 \mathrm{mg} \mathrm{m}^{-3}$, there is a 15\% improvement in the conversion rate for a relative humidity increase from 5 to $50 \%$.

When the amount of water in the gaseous effluent is increased, the excess water molecules compete with the pollutants for the adsorption sites of the photocatalytic media. The number of active sites remains constant, which results in a decrease in photocatalytic activity.

This behavior is observed whatever the inlet pollutant concentration.

Fig.12. Influence of the $\mathrm{RH}$ to different inlet concentrations of chloroform on the CRE with photocatalysis:

$$
\mathrm{Q}=2 \mathrm{~m}^{3} \mathrm{~h}^{-1}, \mathrm{l}=20 \mathrm{~W} \mathrm{~m}^{-2} \text {. }
$$

\subsubsection{Plasma $D B D$ process}

\subsubsection{Removal efficiency}

Relative humidity can significantly alter NTP performance [32,44].Fig.13 shows that CRE increases first and then decreases with $\mathrm{RH}$. In fact, when $\mathrm{RH}$ increases, the competitive effect on the active sites becomes predominant, which leads to a CRE decrease. The optimum $\mathrm{RH}$ value is about $50 \%$ whatever the injected voltage is. As we can previously see for photocatalytic process, the increase of the $\mathrm{RH}$ favors the formation of $\mathrm{OH}^{*}$ radicals which lead to an improvement in the conversion rate. 
During the electronic impact of the plasma on the water molecules, a reaction of decomposition of the water leads to the formation of radicals $\mathrm{OH}^{\circ}$ and $\mathrm{H}^{\circ}[32,34,45]$.

$$
\mathrm{H}_{2} \mathrm{O}+\mathrm{e}^{-} \rightarrow \mathrm{H}^{\bullet}+\mathrm{OH}^{\bullet}+\mathrm{e}^{-} \text {(Eq.13) }
$$

On the other hand, at higher levels of $\mathrm{RH}$, an inverted trend occurs and the $\mathrm{CRE}$ becomes slightly lower. This is because the increase of water vapor content limits the electron density and quenches the active species. This behavior is similar to that reported in the literature [19].

Fig.13. Influence of the RH at different voltages injected on the CRE with plasma DBD alone:

$$
\left[\mathrm{CHCl}_{3}\right]=100 \mathrm{mg} \mathrm{m}^{-3}, \mathrm{Q}=2 \mathrm{~m}^{3} \mathrm{~h}^{-1}, \mathrm{l}=20 \mathrm{~W} \mathrm{~m}^{-2} .
$$

\subsubsection{Plasma $\mathrm{DBD} / \mathrm{TiO}_{2}+U V$}

\subsubsection{Removal efficiency}

Fig.14 shows the variation of CRE as a function of relative humidity at different voltage values. Flow rate and concentration of chloroform were set at $2 \mathrm{~m}^{3} \mathrm{~h}^{-1}$ and $100 \mathrm{mg} \mathrm{m}^{-3}$, respectively. From a qualitative point of view, the obtained results are similar to those in the case of treatment with plasma and photocatalysis. Indeed, there is an optimum level of the chloroform conversion. Similarly, it is found that this optimum (50\%) is not changed with the combination system.

Fig.14. Influence of $\mathrm{RH}$ at different applied voltages on the CRE with plasma $\mathrm{DBD} / \mathrm{TiO}_{2}+\mathrm{UV}$ :

$$
\left[\mathrm{CHCl}_{3}\right]=100 \mathrm{mg} \mathrm{m}^{-3}, \mathrm{Q}=2 \mathrm{~m}^{3} \mathrm{~h}^{-1}, \mathrm{l}=20 \mathrm{~W} \mathrm{~m}^{-2}, \mathrm{~T}=20^{\circ} \mathrm{C} .
$$

\subsubsection{Synergetic effect}

Fig.15 presents the variation of $\mathrm{RS}$ at various voltages and $\mathrm{RH}$ using three processes at a fixed chloroform content obviously, the RS varies from 1.38 to 1.26 for $\mathrm{RH}$ when the $\mathrm{RH}$ varies from 5 to $90 \%$ and RS varies from 1.15 to 1.19 when input voltage varies from 9 to $21 \mathrm{kV}$, respectively. This synergistic effect is observed under different parameters and are in good agreement with those obtained by several groups $[9,11,13,14,38]$.

Fig.15. Variation of $\mathrm{RS}$ with $\mathrm{RH}$ (at $\mathrm{V}=18 \mathrm{kV}$ ) and applied voltage (at $\mathrm{RH}=50 \%$ ) using three processes:

$$
\left[\mathrm{CHCl}_{3}\right]=100 \mathrm{mg} \mathrm{m}^{-3}, \mathrm{Q}=2 \mathrm{~m}^{3} \mathrm{~h}^{-1}, \mathrm{l}=20 \mathrm{~W} \mathrm{~m}^{-2}, \mathrm{~T}=20^{\circ} \mathrm{C} \text {. }
$$




\subsubsection{Intermediate by-products}

\subsection{Injected voltages effect}

Figure16 shows that the increase of the relative humidity (90\%) induces a decrease of the IBE of CO at each value of voltage injected. This decrease is more pronounced at $21 \mathrm{kV}$ : the $1 \mathrm{BE} E_{\mathrm{CO}} 64 \%$ at a $\mathrm{RH}$ of $90 \%$. The $\mathrm{IBE}_{\mathrm{CO}}$ does not exceed to $50 \%$ for the 9 and $12 \mathrm{kV}$.

Similarly, Thevenet et al. [15] showed that, when removing acetylene by cold plasma, the increase of water vapor reduced the amount of $\mathrm{CO}$. For the IBE of $\mathrm{CO}$, the elimination of $\mathrm{CO}$ increases with the voltage (approximately $65 \%$ ). In the case of high humid air (90\%), water vapor leads to the formation of radicals of active oxygen as described in Eq. 13. The decomposition of chloroform gives carbon which reacts with the latter to form $\mathrm{CO}_{2}$

When non-thermal plasma is made in a stream of oxygen-rich gas and water, ozone formation is generally unavoidable. In an earlier research, it has been proposed that the decomposition of ozone by transition metal oxides $\left(\mathrm{TiO}_{2}\right)$ leads to the formation of atomic oxygen (probably $\mathrm{O}_{2}^{\circ}$ ) on the surface of $\mathrm{TiO}_{2}$. On the other hand, the oxidation of $\mathrm{CO}$ and chloroform in the presence of ozone showed that this form was, most likely, the oxidizer. Furthermore, it has been shown that in terms of reactivity, an oxygen atom is a more chemically active species than Ozone [46].

Therefore, it would be favorable for the oxidation reaction if the ozone can be decomposed into one oxygen atom before reacting with $\mathrm{VOC}$ molecules or forming $\mathrm{CO}$. The peroxyl radical $\mathrm{OH}_{2}{ }^{\bullet}$ acts as intermediate active species in the chain mechanism for the transformation of $\mathrm{OH}$ radical and reduces the formation of $\mathrm{CO}$ and ozone.

$$
\mathrm{OH}+\mathrm{CO} \rightarrow \mathrm{CO}_{2}+\mathrm{H}
$$

The IBE of CO increased in voltages above an HR (90\%) (Fig.16). According to the results, plasma $\mathrm{DBD} / \mathrm{TiO}_{2}+\mathrm{UV}$.CO was substantially low in this process, which could be related to low overall CO production, and / or conversion of the $\mathrm{CO}$ formed into $\mathrm{CO}_{2}$ during the oxidation state of the process. Radicals, namely $\mathrm{O}^{\circ}$ and $\mathrm{OH}^{\circ}[47]$, could influence the oxidation of $\mathrm{CO}$ in the reactor $[48,49,50]$. Kogoma et al., reported an exclusive oxidation of $\mathrm{CO}$ with $\mathrm{OH}$ [51]. 
According to (Fig.16), the ozone removal efficiency is higher (between 80 and $87.5 \%$ ) in the highly humid $90 \%$ air.

For coupling, as for plasma, ozone drops with increasing relative humidity. As previously observed, the presence of UV-activated $\mathrm{TiO}_{2}$ in the discharge area slightly reduces ozone formation by a few hundred ppm at high concentrations.

The energy is supplied by UV radiation interacts with ozone. The global reactions were shown in (eq.10) [51].

$$
\begin{aligned}
& \mathrm{O}_{3}+\mathrm{hv}+\mathrm{H}_{2} \mathrm{O} \rightarrow \mathrm{O}_{2}+\mathrm{O}^{\bullet}+2 \mathrm{H}^{\bullet} \\
& \mathrm{H}_{2} \mathrm{O}+\mathrm{O}_{3} \rightarrow \mathrm{H}_{2} \mathrm{O}_{2}+\mathrm{O}_{2} \\
& \mathrm{OH}^{-}+\mathrm{O}_{3} \rightarrow \mathrm{HO}_{2}^{-}+\mathrm{O}_{2}^{-\bullet} \\
& \mathrm{O}_{3}+\mathrm{e}^{-} \rightarrow \mathrm{O}_{3}^{-}
\end{aligned}
$$

Fig.16 shows that, whatever the value of the $\mathrm{RH}$, the increase in the voltage-injected favors the IBE of CO. This is explained by the fact that, at high energy values, electrical discharges produce more reactive species that allow for further degradation (mineralization) of the pollutant.

Fig.16. Variation the IBE of ozone and CO with applied voltage:

$\left[\mathrm{CHCl}_{3}\right]=100 \mathrm{mg} \mathrm{m}^{-3}, \mathrm{Q}=2 \mathrm{~m}^{3} \mathrm{~h}^{-1}, \mathrm{RH}=90 \%, \mathrm{I}=20 \mathrm{~W} \mathrm{~m}^{-2}, \mathrm{~T}=20^{\circ} \mathrm{C}$.

Several studies on plasma photocatalytic $[33,53]$ assumed that the reduction of the amount of carbon monoxide is related to the increase of the pathway favoring the formation of other intermediates reaction than CO.

\subsection{Relative humidity effect:}

Figure 17shows that the increasing the relative humidity of the air reduces the ozone production. Indeed, the elimination of ozone with the coupling reaches to $85 \%$.

First of all, it can be seen (Fig.17) that when water vapor (from 50 to 90\%) is added, the ozone depletion is increasingly important to the voltage value applied $18 \mathrm{kV}$. Ozone can be decomposed by the effect of the radicals $\mathrm{H}^{\circ}$ and $\mathrm{HO}^{\circ}$ according to the following reactions [15,37]:

$$
\mathrm{O}_{3}+\mathrm{OH}^{\bullet} \rightarrow \mathrm{O}_{2}+\mathrm{OH}_{2}^{\cdot}
$$




$$
\mathrm{O}_{3}+\mathrm{H}^{\bullet} \rightarrow \mathrm{O}_{2}+\mathrm{HO}^{\bullet}
$$

Radical recombination reactions can also occur according to the following reaction [54]:

$$
\mathrm{OH}^{\bullet}+\mathrm{O}^{\bullet} \rightarrow \mathrm{H}^{\bullet}+\mathrm{O}_{2} \quad \text { (Eq.20) }
$$

This phenomenon appears as an indication that ozone is not the main oxidizing species, but only a marker. Despite the reduction of ozone in the moisture range from 5 to $50 \%$, the conversion rate increases with the $\mathrm{RH}$ in the same range.

As previously observed with photocatalysis alone, the increase of moisture favors the formation of $\mathrm{OH}^{\circ}$ radicals while leads to an improvement of the IBE level in the plasma zone. When electron plasma is impacted on water molecules, a decomposition reaction of the latter leads to the formation of $\mathrm{OH}^{*}$ and $\mathrm{H}^{*}$ radicals $[43,55]$.

Regarding the $\mathrm{OH}^{\circ}$ radicals and the efficiency of their formation reaction, the concentration downstream of the reactor and the rate of occurrence are proportional to the voltages applied in the device. Thus, their effect on the process performance appears for High voltage values [33].

With the increase of relative humidity, $\mathrm{OH}^{\circ}$ radicals are formed, their probability of recombination and the interaction with certain species generated from $\mathrm{O}_{2}$ by the plasma discharge, such as atomic oxygen, are also increased [56]. In the presence of water, the reaction medium a modification of the potentially oxidizing species is taken. Under dry air, these are $\mathrm{O}^{\circ}$ and $\mathrm{O}_{3}$, while in humid air they are replaced by $\mathrm{OH}^{\circ}$. Other studies [33] show that the formation of hydrogen peroxide dominates the kinetics process when water is added. $\mathrm{H}_{2} \mathrm{O}_{2}$ is formed by the recombination of two $\mathrm{OH}^{\circ}$ radicals.

Ozone can be decomposed by the effect of the radicals $\mathrm{H}^{\circ}$ and $\mathrm{HO}^{\circ}$ according to the following reactions (Eq. 18-19) [45,57]:

Fig.17. Variation the IBE of ozone and $\mathrm{CO}$ with $\mathrm{RH}$ : $\left[\mathrm{CHCl}_{3}\right]=100 \mathrm{mg} \mathrm{m}^{-3}, \mathrm{Q}=2 \mathrm{~m}^{3} \mathrm{~h}^{-1}, \mathrm{~V}=18 \mathrm{kV}, \mathrm{l}=20 \mathrm{~W} \mathrm{~m}^{-2}, \mathrm{~T}=20^{\circ} \mathrm{C}$.

\subsection{Others intermediates by-products:}

We wanted to follow closely the degradation of Trichloromethane, so we decided to identify the degradation by-products by gas chromatography coupled to mass spectrometry (GC-MS). Thus, the by-products generated during the plasma, photocatalysis and combined process degradation of Trichloromethane were identified using a Gas chromatography-mass spectrometry (GC-MS) Perkin Elmer Clarus 500. The GC-MS column is a 25 m long Chrompac TM capillary column FFAP-CB, its 
diameter is $0.15 \mathrm{~mm}$ and the stationary phase's thickness is $0.25 \mathrm{~m}$. Due to their low concentrations, by-products are concentrated on a Carbotrap $(25 \mathrm{ml})$ then its content is removed using thermal desorption unit coupled with the GC-MS

Three samples were taken for Trichloromethane after each treatment process. Analyses of outlet unpolluted air flow composition after its treatment with each of the three processes have also been made in order to suppress any doubt while identifying Trichloromethane intermediates. The results are shown in figure 18.

Figure 18: By-products identified by GC-MS following Trichloromethane oxidation by the Three tested systems

Compounds present in the outlet air were detected by GC-MS. Regarding Trichloromethane as pure substance and its oxidation by plasma system; the detected degradation by-products were acetone, ethanol, methanol $\mathrm{CCl} 4$ and acetaldehyde. Trichloromethane is also detected at 5,75min. The same intermediates as in combined system were detected when plasma was used alone. We note that, after treatment by photocatalysis, the presence of acetone and methanol (Figure 18).

\section{CONCLUSIONS}

This work deals to compare the behavior of the effectiveness of chloroform removal in a cylindrical reactor by photocatalysis $\left(\mathrm{TiO}_{2}+\mathrm{UV}\right)$, DBD plasma and combined processes.

At high flow rate, the oxidation process, generated by three systems seems to be controlled by the mass transfer step. Moreover, this study showed that combination of the plasma with photocatalysis improves the performance of the pollutant decomposition process. In fact, chloroform removal efficiency by combined process is higher than the sum of both photocatalysis and plasma DBD alone. Intermediate byproducts of chloroform with each process were identified. 


\section{References}

[1] ADEME (2005) Pollutions olfactives : origine, législation, analyse, traitement. ADEME, Dunod, Angers.

[2] F.G. Shahna,H. Ebrahimi,B. Jaleh,A. Bahrami, (2015) Decomposition of gas-phase chloroform using nanophotocatalyst downstream the novel non-thermal plasma reactor: by-products elimination. International Journal of Environmental Science and Technology, 12(11), 3489-3498.

[3] C.Subrahmanyam, M. Magureanu, D. Laub, A. Renken, L. Kiwi-Minsker,(2007) Nonthermal plasma abatement of trichloroethylene enhanced by photocatalysis. J Phys Chem C 111(11):4315-4318.

[4] B. Ramaraju, C. Subrahmanyam, (2014). Catalytic non-thermal plasma reactor for stripping the VOCs from air. Composite Interfaces, 21(7), 651-658.

[5] A.M. Vandenbroucke, R. Morent, N. De Geyter, Ch. Leys, (2011) Non-thermal plasmas for noncatalytic and catalytic VOC abatement, Journal of Hazardous Materials 195, 30-54.

[6]J. Van Durme, J. Dewulf, C. Leys, H. Van Langenhove, (2008) Combining non-thermal plasma with heterogeneous catalysis in waste gas treatment: A review, Applied Catalysis B: Environmental 78, 324-333.

[7] P. Pichat,(2010) Some views about indoor air photocatalytic treatment using $\mathrm{TiO}_{2}$ : conceptualization of humidity effects, active oxygen species, problem of C1-C3 carbonyl pollutants, Appl. Catal. B: Environ. 99, 428-434.

[8] P. Pichat, J. Disdier, C. Hoang-Van, D. Mas, G. Goutailler, C. Gaysse,(2000) Purification/ deodorization of indoor air and gaseous effluents by TiO2 photocatalysis, Catal. Today 63, 363-369. [9] A.A. Assadi, A. Bouzaza, D. Wolbert, (2012) Photocatalytic oxidation of trimethylamine and isovaleraldehyde in an annular reactor: influence of the mass transfer and the relative humidity, $\mathrm{J}$. Photochem. Photobiol. A: Chem. 236, 61-69.

[10] A. Bouzaza, C. Vallet, A. Laplanche,(2006) Photocatalytic degradation of some VOCs in the gas phase using an annular flow reactor: determination of the contribution of mass transfer and chemical reaction steps in the photodegradation process, J. Photochem. Photobiol. A: Chem. 177, 212-217.

[11] A.A. Assadi, J. Palau, A. Bouzaza, J. Penya-Roja, V. Martinez-Soria, D. Wolbert, (2014a) Abatement of 3-methylbutanal and trimethylamine with combined plasma and photocatalysis in a continuous planar reactor, J. Photochem. Photobiol. A: Chem. 282, 1-8. 
[12] J. Taranto, D. Frochot, P. Pichat,(2007) Combining cold plasma and $\mathrm{TiO}_{2}$ photocatalysis to purify gaseous effluents: a preliminary study using methanol-contaminated air, Ind. Eng. Chem. Res. 46, 7611-7614.

[13] Y. Lu, D. Wang, Y. Wu, C. Ma, X. Zhang, C. Yang, (2012) Synergistic effect of nanophotocatalysis and non-thermal plasma on the removal of indoor HCHO. Int J Photoenergy 2012:1-8.

[14] A. Maciuca, C. Batiot-Dupeyrat, J-M.Tatiboueët, (2012) synergetic effect by coupling photocatalysis with plasma for low VOCs concentration removal from air. ApplCatal B 125:432-438.

[15] F. Thevenet, O. Guaitella, E. Puzenat, J-M. Herrmann, A. Rousseau, C. Guillard, (2007) Oxidation of acetylene by photocatalysis coupled with dielectric barrier discharge. Catal Today 122(1):186-194.

[16] A. M. Vandenbroucke, M. Mora, C. Jiménez-Sanchidrián, F. J. Romero-Salguero, N. De Geyter, C. Leys, R. Morent, (2014) TCE abatement with a plasma-catalytic combined system using $\mathrm{MnO}_{2}$ as catalyst, Applied Catalysis B: Environmental 156, 94-100.

[17] Y. Li, Z. Fan, J. Shi, Z. Liu, W. Shangguan, (2014) Post plasma-catalysis for VOCs degradation over different phase structure MnO2 catalysts, Chemical Engineering Journal 241, 251-258.

[18] W. Abou Saoud, A. A. Assadi, M. Guiza, A. Bouzaza, W. Aboussaoud, A. Ouederni, I. Soutrel, D. Wolbert, S. Rtimi, (2017) Study of synergetic effect, catalytic poisoning and regeneration using dielectric barrier discharge and photocatalysis in a continuous reactor: Abatement of pollutants in air mixture system, Applied Catalysis B: Environmental, 213, 53-61,

[19] H. Huang, D. Ye,(2009) Combination of photocatalysis downstream the non-thermal plasma reactor for oxidation of gas-phase toluene.J Hazard Mater 171(1):535-541.

[20] INERIS, (2014) Données technico-économiques sur les substances chimiques en France : chloroforme, DRC-14-136877-04843A, $41 \mathrm{p}$.

[21] W. Elfalleh, A.A. Assadi, A. Bouzaza, D. Wolbert, J. Kiwi, S. Rtimi, (2017) Innovative and stable TiO2 supported catalytic surfaces removing aldehydes under UV-light irradiation,Journal of Photochemistry and Photobiology A: Chemistry, 343,96-102,

[22] Publication of Final Decision on the Assessment of a Substance - Chloroform - Specified on the Priority Substances List (Subsection 77(6) of the Canadian Environmental Protection Act, 1999) (PDF 6.10 MB, go to page 34), 2001-03-24 - Canada Gazette - Part I, Vol. 135 No. 12.

[23] I. Kempen, M. Hemmer, S. Counerotte, L. Pochet, P. de Tullio, J-M. Foidart, S. Blacher, A. Noël, F. Frankenne, B. Pirotte,(2008), 6-Substituted 2-oxo-2H-1-benzopyran-3-carboxylic acid derivatives in 
a new approach of the treatment of cancer cell invasion and metastasis. European Journal of Medicinal Chemistry, vol. 43, iss. 12, pp. 2735-2750.

[24] Ahlstrom Patent EP 1069950, 2000. AU 735798 US 09/467, 650; JP 2000-542104.

[25] J. Rodier, (1996). The Analysis of Water: Natural Water. Wastewater, Sea Water: Physical, Chemistry, Bacteriology and Biology. 8th Edition, Dunod Ltd, Paris.

[26] K-H. Wang, H-H. Tsai, Y-H. Hsieh, (1998). The kinetics of photocatalytic degradation of trichloroethylene in gas phase over $\mathrm{TiO}_{2}$ supported on glass bead, Applied Catalysis $\mathrm{B}$ : Environmental $17,313-320$.

[27]R.H. Perry, D. Green, J.O. Maloney, (1997). Perry's Chemical Engineers's Handbook, $7^{\text {th }}$ ed., Mc Graw-Hill Book Company, New-York.

[28]A.A. Mobarak, H.A. Farag, G.H. Sedahmed, Mass transfer in smooth and rough annular ducts under developing flow conditions, Journal of Applied Electrochemistry.

[29] A.A. Assadi, A. Bouzaza, C. Vallet, D. Wolbert, (2014b) Use of DBD plasma, photocatalysis and combined DBD plasma/ photocatalysis in a continuous annular reactor for isovaleraldehyde elimination - Synergetic effect and byproducts identification, Chem. Eng. J. 124-132

[30] S. Gharib-AbouGhaida, A.A. Assadi, G. Costa, A. Bouzaza, D. Wolbert, (2016) Association of surface dielectric barrier discharge and photocatalysis in continuous reactor at pilot scale: Butyraldehyde oxidation, by-products identification and ozone valorization, Chem. Eng. J. 276-283

[31] L. Sivachandiran, F. Thevenet, P. Gravejat, A. Rousseau, Isopropanol saturated $\mathrm{TiO}_{2}$ surface regeneration by non-thermal plasma: influence of air relative humidity, Chem. Eng. J. (2013) 17-26

[32] A.A. Assadi, A. Bouzaza, M. Lemasle, D. Wolbert, (2015). Removal of trimethylamine and isovaleric acid from gas streams in a continuous flow surface discharge plasma reactor. chemical engineering research and design 93, 640-651.

[33] G Maxime, AA Amine, B Abdelkrim, W Dominique (2014) Removal of gas-phase ammonia and hydrogen sulfide using photocatalysis, nonthermal plasma, and combined plasma and photocatalysis at pilot scale, Environmental Science and Pollution Research 21 (22), 13127-13137.

[34] Y. Nakagawa, R. Ono, T. Oda, (2014). Investigation of humidity effect on atmospheric plasma decomposition of toxic gas with direct optical measurement of oh radicals. IEEE Transactions on industry applications, vol. 50, no. 1. 
[35] A. A. Assadi, A. Bouzaza, S. Merabet, D. Wolbert, (2014c) modeling and simulation of VOCs removal by nonthermal plasma discharge with photocatalysis in a continuous reactor: Synergetic effect and mass transfer, Chemical Engineering Journal, 258, 119-127,

[36] S. DELAGRANGE, L, PINARD, J.M. TATIBOUET, (2007). Combination of a non-thermal plasma and a catalyst for toluene removal from air: Manganese based oxide catalysts, Appl. Catal. B: Environ. 68. 92-98.

[37] A.A. Assadi, A. Bouzaza, I. Soutrel, P. Petit, K. Medimagh, D. Wolbert. (2017). A study of pollution removal in exhaust gases from animal quartering centers by combining photocatalysis with surface discharge plasma: From pilot to industrial scale. Chemical Engineering and Processing 111, $1-6$.

[38] C. He, L. Cao, X. Liu, W. Fu, J. Zhao.(2015). Catalytic behavior and synergistic effect of nonthermal plasma and CUO/AC catalyst for benzene destruction. International Journal of Environmental Science and Technology, 12(11), 3531-3540.

[39] Q. Geng, Q. Guo, X. Yue. (2010), Adsorption and Photocatalytic Degradation Kinetics of Gaseous cyclohexane in an Annular Fluidized Bed Photocatalytic Reactor, Ind. Eng. Chem. Res. 49 : 46444465.

[40] B. Boulinguiez, A. Bouzaza, S. Merabet, D. Wolbert, (2008), Photocatalytic degradation of ammonia and butyric acid in plug-flow reactor: Degradation kinetic modeling with contribution of mass transfer. Journal of Photochemistry and Photobiology A: Chemistry, 200: 254-261.

[41] F. Thevenet, O Guaitella, J.M. Herrmann, A. Rousseau, C. Guillard, (2005), Photocatalytic degradation of acetylene over various titanium dioxide-based photocatalysts. Applied Catalysis B: Environmental, 61(1), 58-68.

[42] AA Assadi, A Bouzaza, D Wolbert (2015) Study of synergetic effect by surface discharge plasma/TiO2 combination for indoor air treatment: Sequential and continuous configurations at pilot scale, Journal of Photochemistry and Photobiology A: Chemistry 310, 148-154

[43] T. Ochiai, A. Fujishima, (2012). Photoelectrochemical properties of $\mathrm{TiO}_{2}$ photocatalyst and its applications for environmental purification, Journal of Photochemistry and Photobiology C: Photochemistry Reviews 13, 247-262.

[44] A.M. Vandenbroucke, R. Morent, N. De Geyter, CH.Leys, (2011). Non-thermal plasmas for noncatalytic and catalytic VOCabatement. J. Hazard. Mater. 195, 30-54. 
[45] Y. Guo, X. Liao, D. Ye, (2008), Detection of hydroxyl radical in plasma reaction on toluene removal Journal of Environmental Sciences, 20, 1429-1432.

[46] A. Naydenov, R. Stoyanova, D. Mehandjiev, (1995) Journal of Molecular Catalysis A: Chemical $98,9$.

[47] V.I. Parvulescu, M. Magureanu, P. Lukes, (2013) Plasma Chemistry and Catalysis in Gases and Liquids, Wiley.

[48] H. Ge, D. Hu, X. Li, Y. Tian, Z. Chen, Y. Zhu, (2015) Removal of low-concentration benzene in indoor air with plasma-MnO2 catalysis system, J. Electrost. 76, 216-221.

[49] S. Zhang, X.-S. Li, B. Zhu, J.-L. Liu, X. Zhu, A.-M. Zhu, B.W.L. Jang, (2015) Atmosphericpressure O2 plasma treatment of Au/TiO2 catalysts for CO oxidation, Catal. Today 256 (Part 1), 142-147.

[50] S. Zhang, X.-S. Li, B. Chen, X. Zhu, C. Shi, A.-M. Zhu, (2014) CO oxidation activity at room temperature over $\mathrm{Au} / \mathrm{CeO} 2$ catalysts: disclosure of induction period and humidity effect, ACS Catal. 4 , 3481-3489.

[51] M. Kogoma, Y. Miki, K. Tanaka, K. Takahashi, (2006) Highly efficient VOC decomposition using a complex system (OH radical, ozone-UV, and TiO2), Plasma Process. Polym. 3, 727-733.

[52] LEYS, Christophe et MORENT, Rino. VOC removal from air by plasma-assisted catalysis: mechanisms, interactions between plasma and catalysts. Plasma Chemistry and Catalysis in Gases and Liquids, 2012, p. 171-184.

[53] K. Allegraud, O. Guaitella, A. Rousseau, (2007). Spatio-temporal breakdown in surface DBDs: evidence of collective effect. Journal of Physics D: Applied Physics, 40(24), 7698.

[54] D. L. Baulch, C. T. Bowman, C. J. Cobos, R. A. Cox, T. Just, J. A. Kerr, M. J. Pilling, D. Stocker, J. Troe, W. Tsang, R. W. Walker, and J. Warnatz, (2005) "Evaluated kinetic data for combustion modeling: Supplement II," J. Phys. Chem. Ref. Data, vol. 34, no. 3, pp. 757-1398.

[55] R. Atkinson, J. Arey, (2003). Atmospheric degradation of volatile organic compounds. Chemical reviews, 103 (12), 4605-4638.

[56]L. Z. Wang, J. Song, (2006). Piezoelectric nano-generators based on zinc oxide nanowire arrays. Science, 312(5771), 242-246.

[57] M. Capitelli, C. Gorse, S. Longo, D. Giordano, (2000). Collision integrals of high-temperature air species. Journal of thermophysics and heat transfer, 14(2), 259-268. 


\section{Figures}

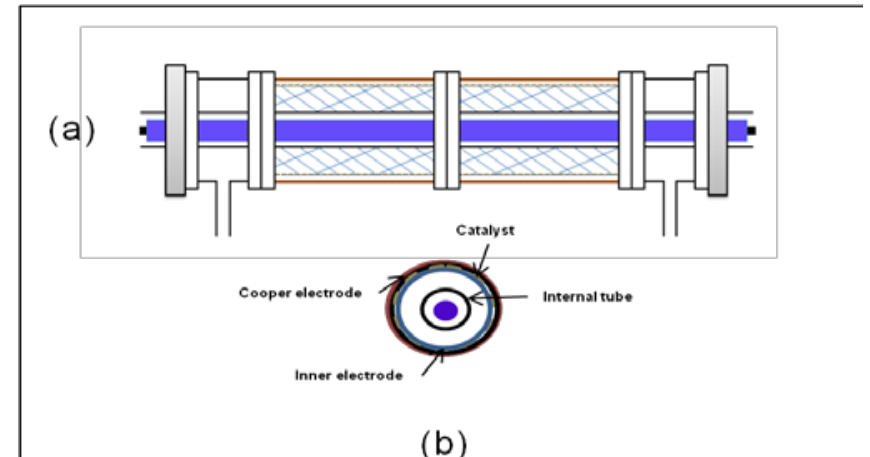

Fig.1. Drawing of the cylindrical photo reactor (a) and the cross-section (b).

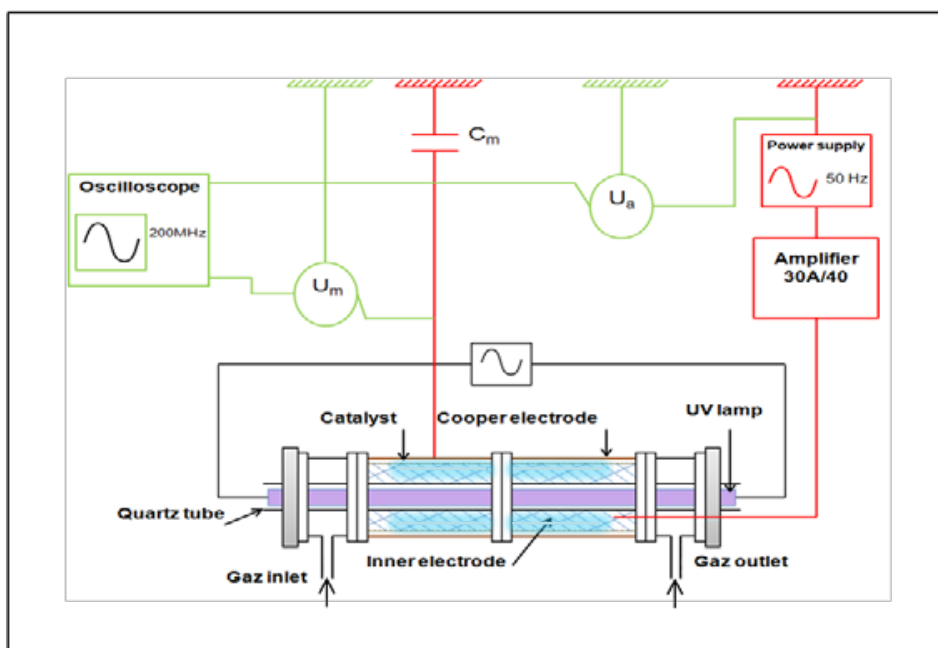

Fig.2. General Schematic view the circuit electric of the photocatalysis and plasma DBD in an annular reactor.

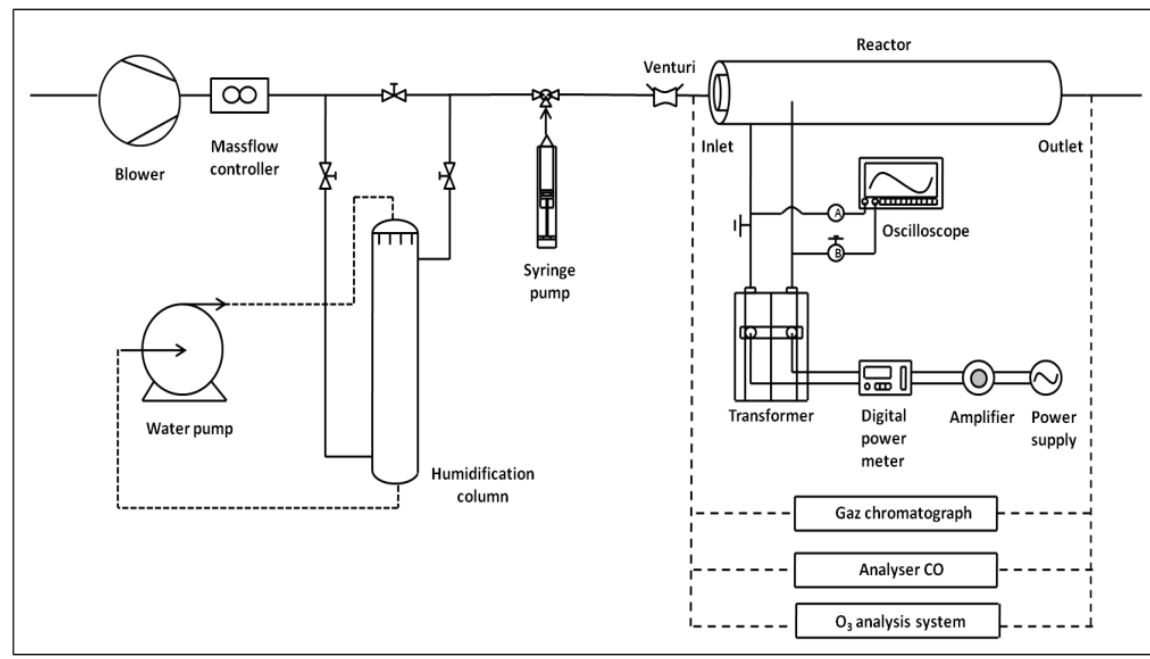

Fig.3. General Schematic view of the pilot system: photocatalysis and plasma DBD. 


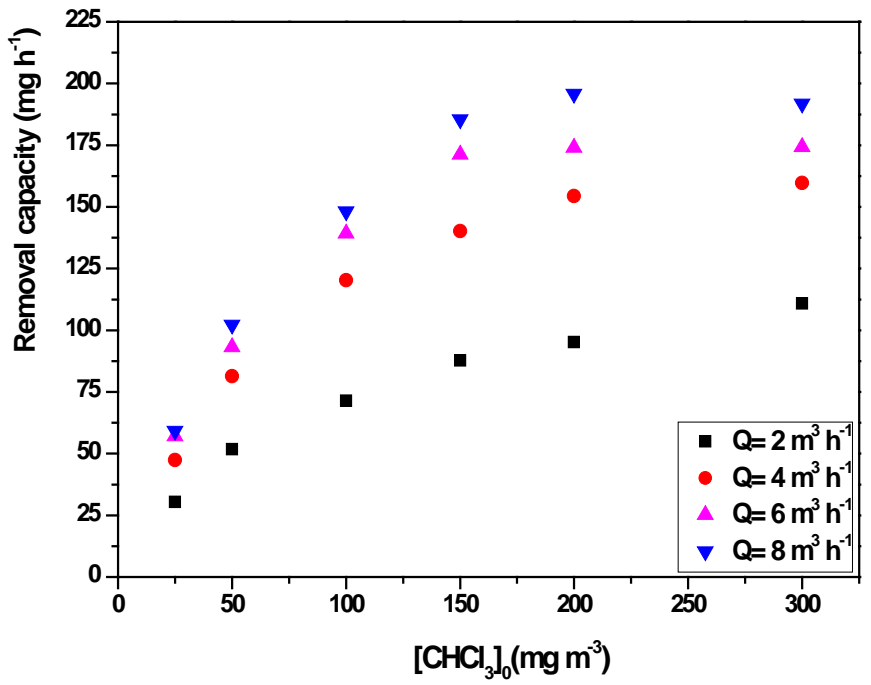

Fig 4: Influence of gas flow rates and inlet concentrations on the removal capacity of chloroform by photocatalysis alone: $\mathrm{RH}=50 \%, \mathrm{~T}=20^{\circ} \mathrm{C}, \mathrm{I}=20 \mathrm{~W} \mathrm{~m}^{-2}$.

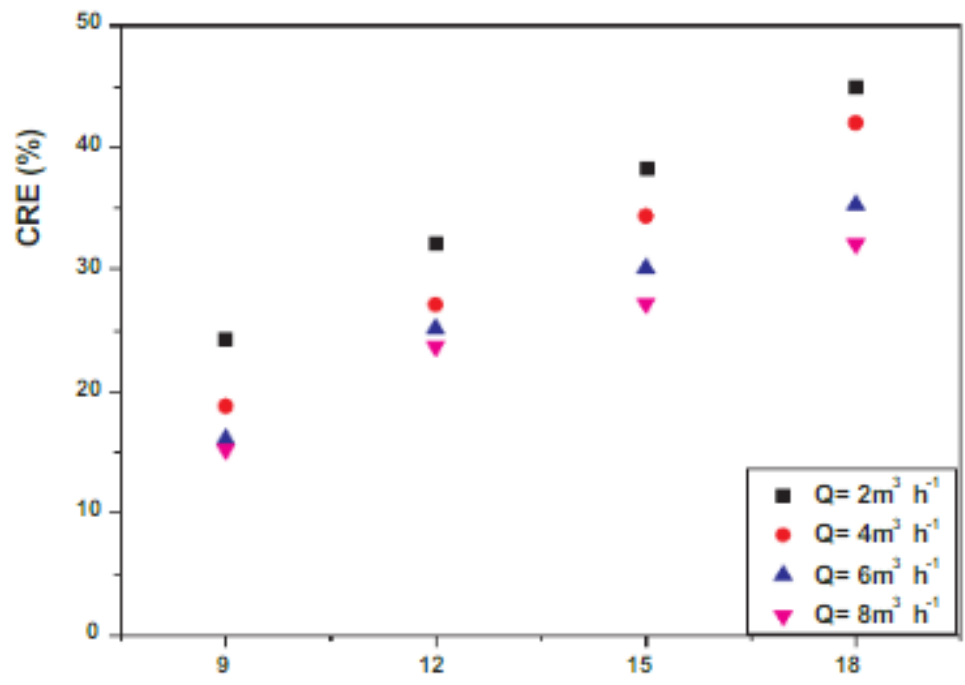

Applied Voltage (kV)

Fig. 5. Influence of applied voltages at different flow rates on the CRE in plasma alone: $[\mathrm{CHCl} 3]=100 \mathrm{mg} \mathrm{m}-3, \mathrm{HR}=50 \%, \mathrm{~T}=20^{\circ} \mathrm{C}$. 


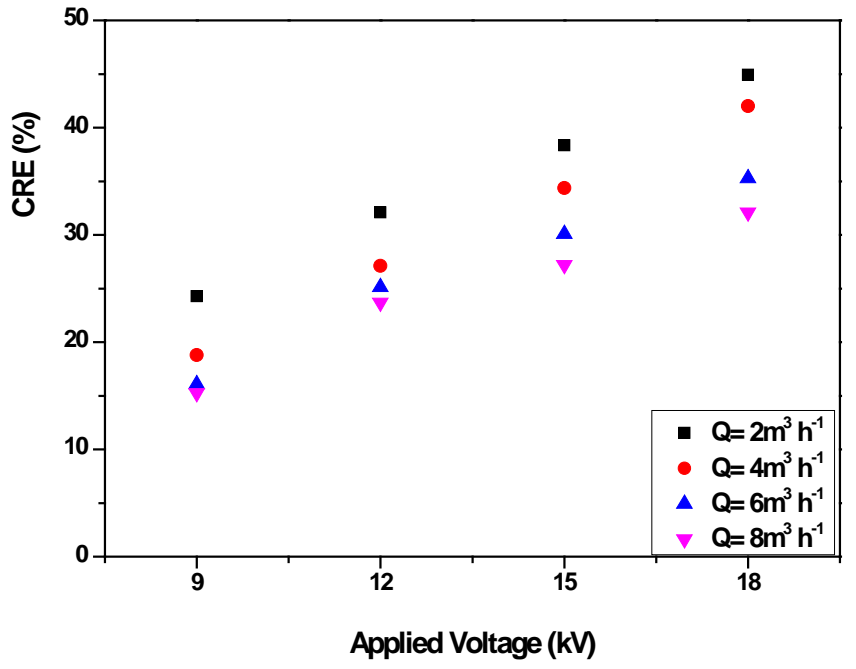

Fig.6. Influence of applied voltages at different flow rates on the $\mathrm{CRE}$ in plasma alone:

$\left[\mathrm{CHCl}_{3}\right]=100 \mathrm{mg} \mathrm{m}^{-3}, \mathrm{HR}=50 \%, \mathrm{~T}=20^{\circ} \mathrm{C}$

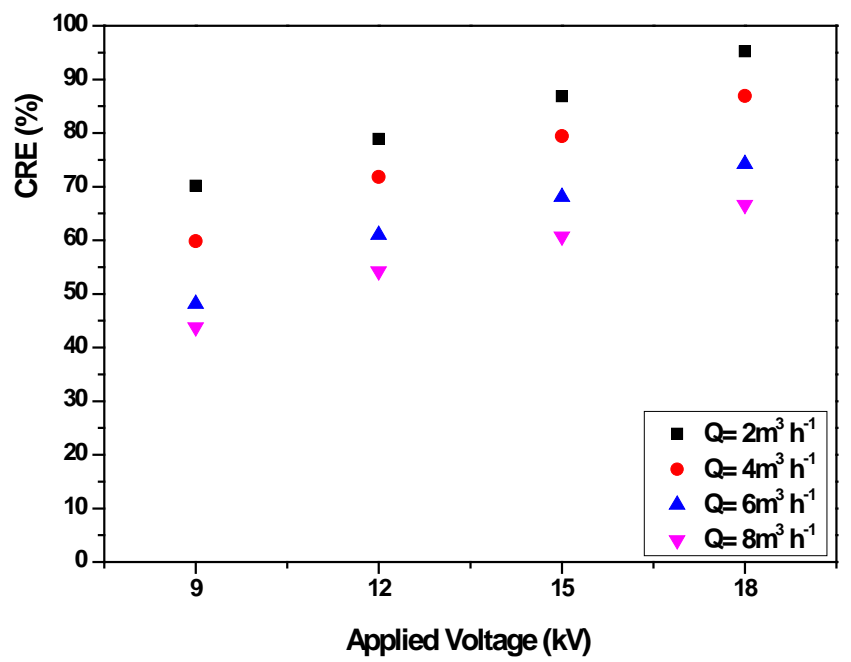

Fig.7. Influence of voltages injected at different flow rates on the CRE with plasma $\mathrm{DBD} / \mathrm{TiO}_{2}+\mathrm{UV}$ : $\left[\mathrm{CHCl}_{3}\right]=100 \mathrm{mg} \mathrm{m}^{-3}, \mathrm{RH}=50 \%, \mathrm{l}=20 \mathrm{~W} \mathrm{~m}^{-2}, \mathrm{~T}=20^{\circ} \mathrm{C}$. 


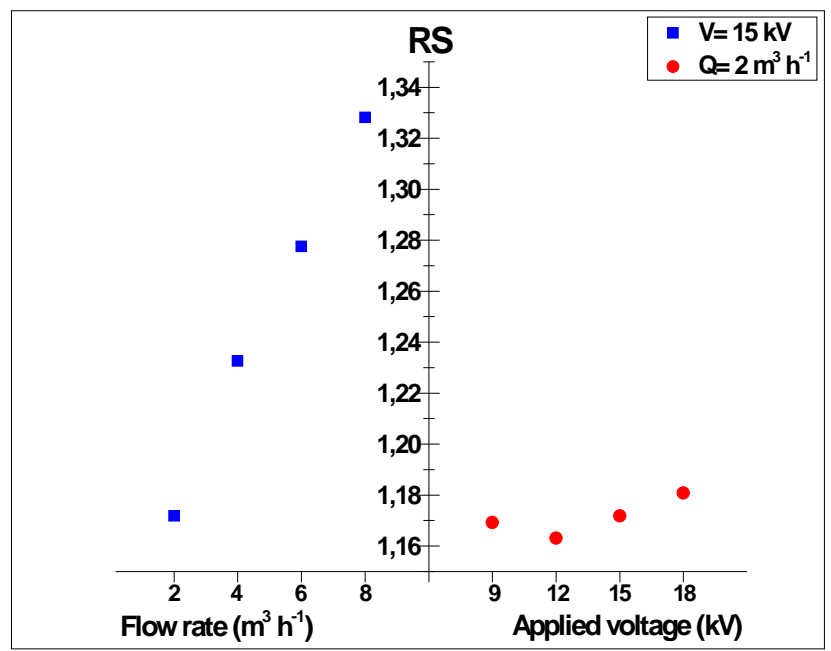

Fig.8. Variation of RS with flow rate (at $\mathrm{V}=15 \mathrm{kV}$ ) and applied voltage (at $\mathrm{Q}=2 \mathrm{~m}^{3} \mathrm{~h}^{-1}$ ) using three processes: $\left[\mathrm{CHCl}_{3}\right]=100 \mathrm{mg} \mathrm{m}^{-3}, \mathrm{RH}=50 \%, \mathrm{l}=20 \mathrm{~W} \mathrm{~m}^{2}, \mathrm{~T}=20^{\circ} \mathrm{C}$.

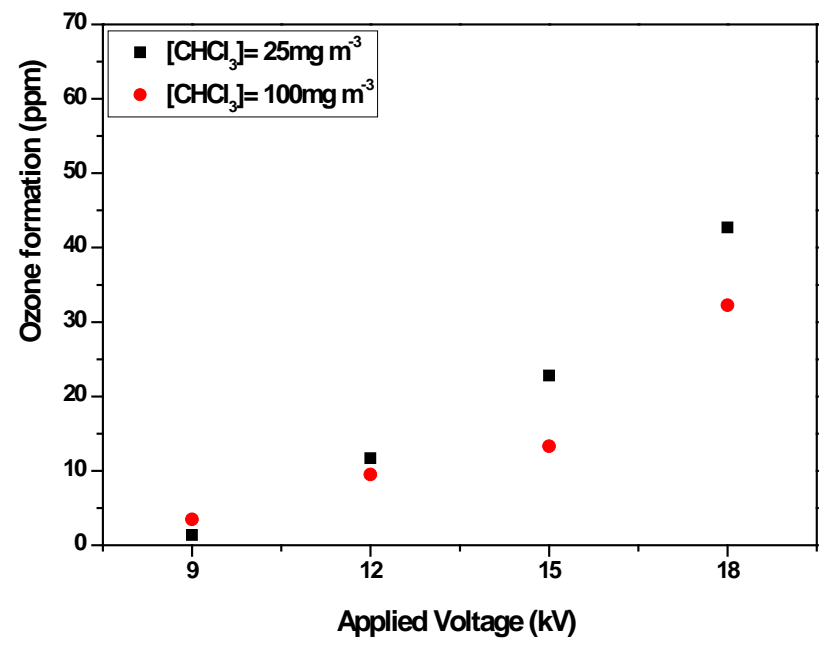

Fig.9. Influence of applied voltages at different inlet concentrations on ozone formation with plasma/TiO ${ }_{2}+U V$ : $\mathrm{HR}=50 \%, \mathrm{~T}=20^{\circ} \mathrm{C}$ 


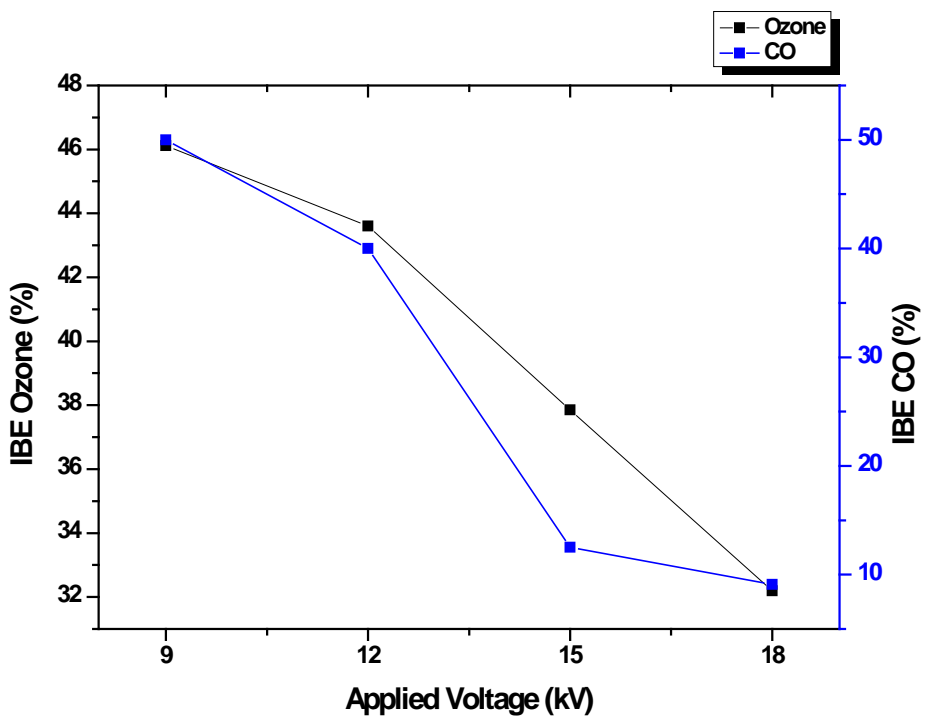

Fig.10. Variation the IBE of ozone and CO with applied voltage: $\left[\mathrm{CHCl}_{3}\right]=100 \mathrm{mg} \mathrm{m}^{-3}, \mathrm{Q}=6 \mathrm{~m}^{3} \mathrm{~h}^{-1}, \mathrm{RH}=50 \%, \mathrm{l}=20 \mathrm{~W} \mathrm{~m}^{-2}, \mathrm{~T}=20^{\circ} \mathrm{C}$.

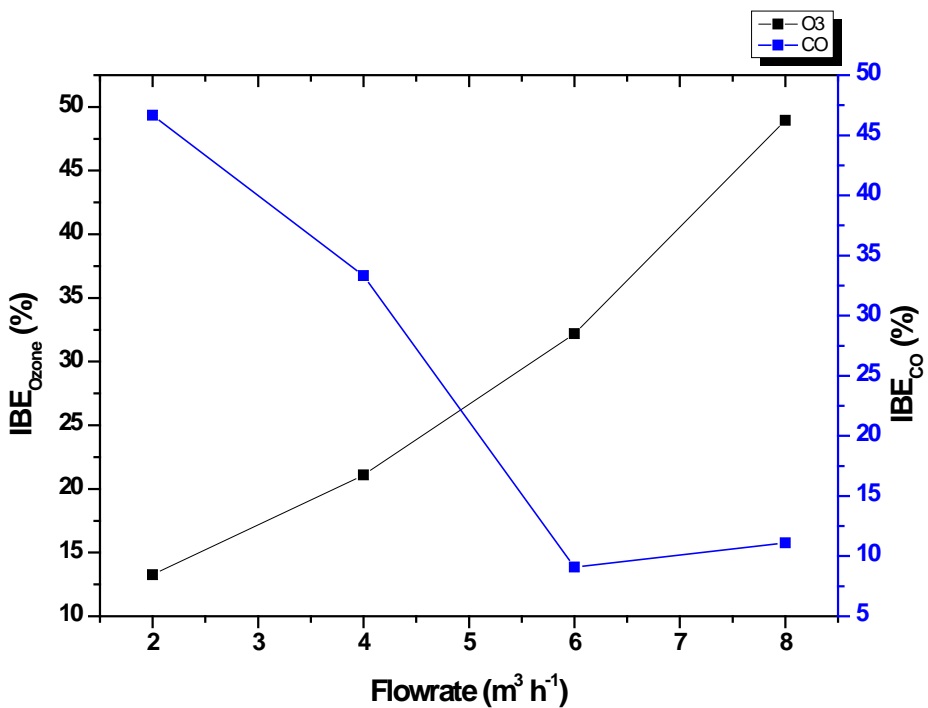

Fig.11. Variation the IBE of ozone and $\mathrm{CO}$ with flow rate:

$\left[\mathrm{CHCl}_{3}\right]=100 \mathrm{mg} \mathrm{m}^{-3}, \mathrm{~V}=18 \mathrm{kV}, \mathrm{RH}=50 \%, \mathrm{l}=20 \mathrm{~W} \mathrm{~m}^{-2}, \mathrm{~T}=20^{\circ} \mathrm{C}$. 


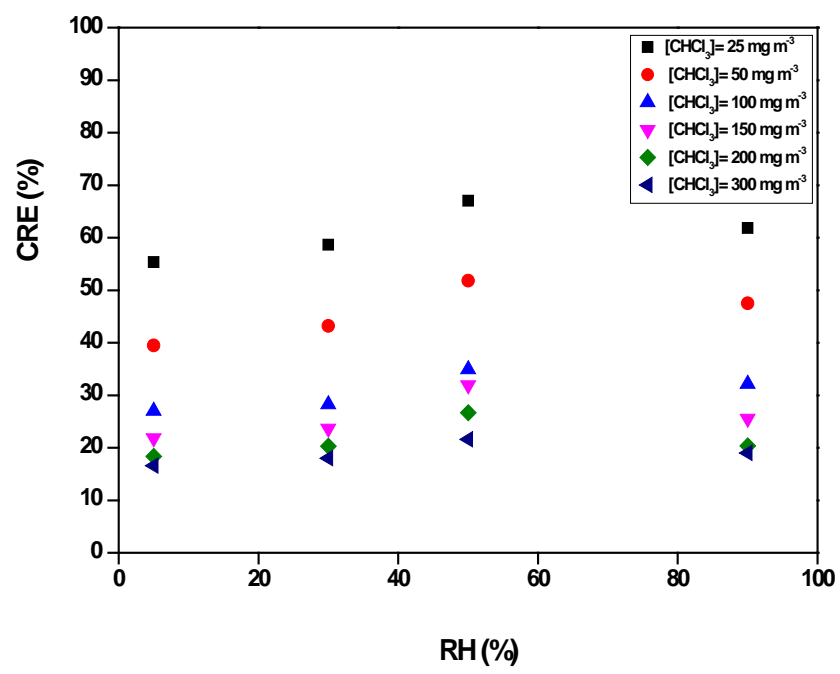

Fig.12. Influence of the $\mathrm{RH}$ to different inlet concentrations of chloroform on the CRE with photocatalysis: $\mathrm{Q}=2 \mathrm{~m}^{3} \mathrm{~h}^{-1}, \mathrm{l}=20 \mathrm{~W} \mathrm{~m}^{-2}$.

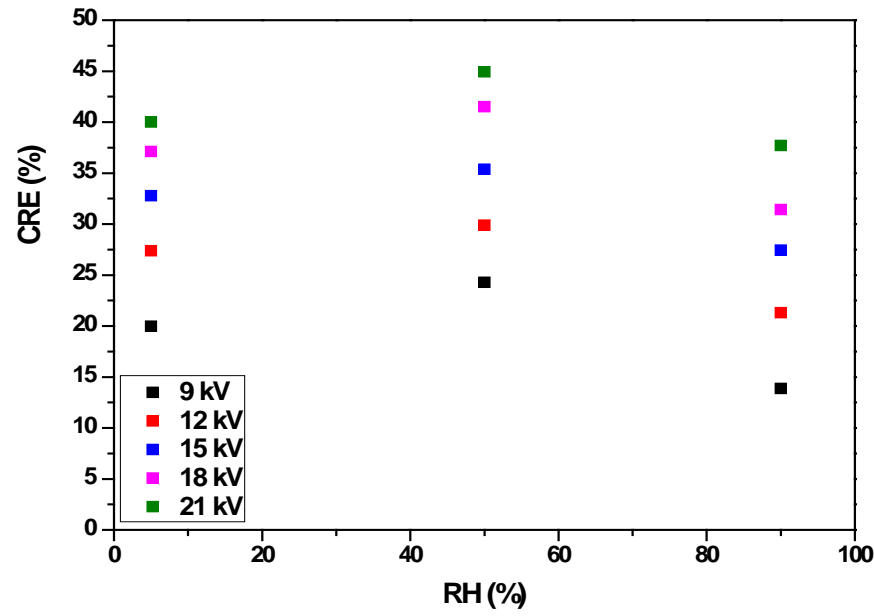

Fig.13. Influence of the $\mathrm{RH}$ at different voltages injected on the CRE with plasma DBD alone: $\left[\mathrm{CHCl}_{3}\right]=100 \mathrm{mg} \mathrm{m}^{-3}, \mathrm{Q}=2 \mathrm{~m}^{3} \mathrm{~h}^{-1}, \mathrm{l}=20 \mathrm{~W} \mathrm{~m}^{-2}$. 


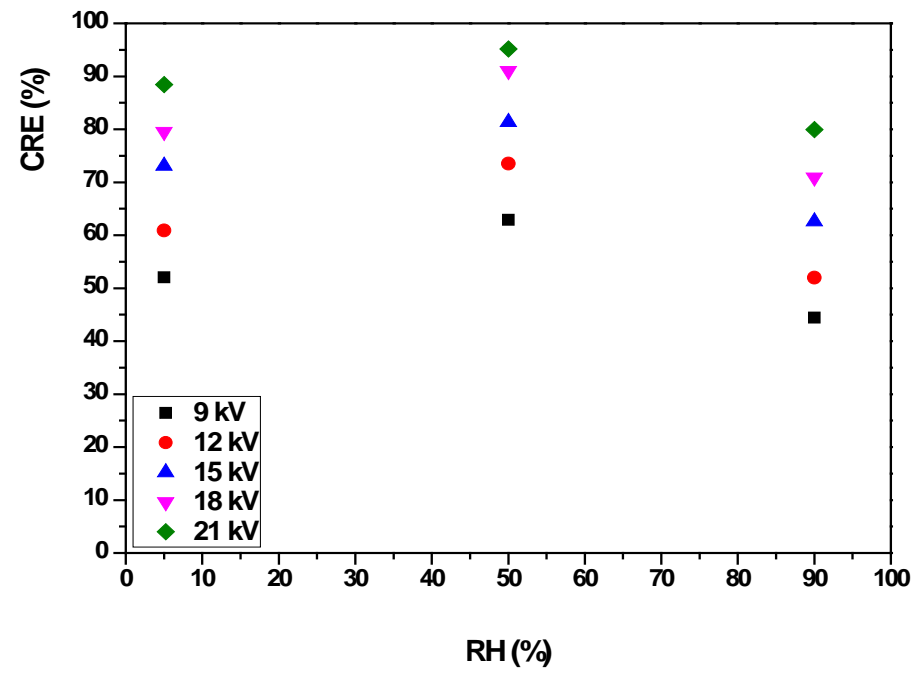

Fig.14. Influence of $\mathrm{RH}$ at different applied voltages on the $\mathrm{CRE}$ with plasma $\mathrm{DBD} / \mathrm{TiO} \mathrm{O}_{2}+\mathrm{UV}$ : $\left[\mathrm{CHCl}_{3}\right]=100 \mathrm{mg} \mathrm{m}^{-3}, \mathrm{Q}=2 \mathrm{~m}^{3} \mathrm{~h}^{-1}, \mathrm{l}=20 \mathrm{~W} \mathrm{~m}^{-2}, \mathrm{~T}=20^{\circ} \mathrm{C}$.

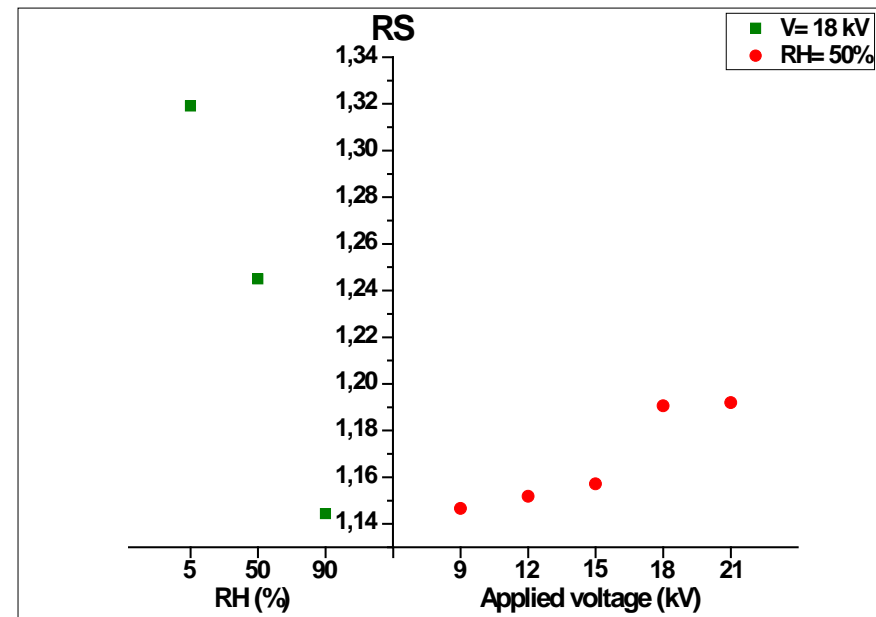

Fig.15. Variation of $\mathrm{RS}$ with $\mathrm{RH}$ (at $\mathrm{V}=18 \mathrm{kV}$ ) and applied voltage (at $\mathrm{RH}=50 \%$ ) using three processes: $\left[\mathrm{CHCl}_{3}\right]=100 \mathrm{mg} \mathrm{m}^{-3}, \mathrm{Q}=2 \mathrm{~m}^{3} \mathrm{~h}^{-1}, \mathrm{l}=20 \mathrm{~W} \mathrm{~m}^{-2}, \mathrm{~T}=20^{\circ} \mathrm{C}$. 


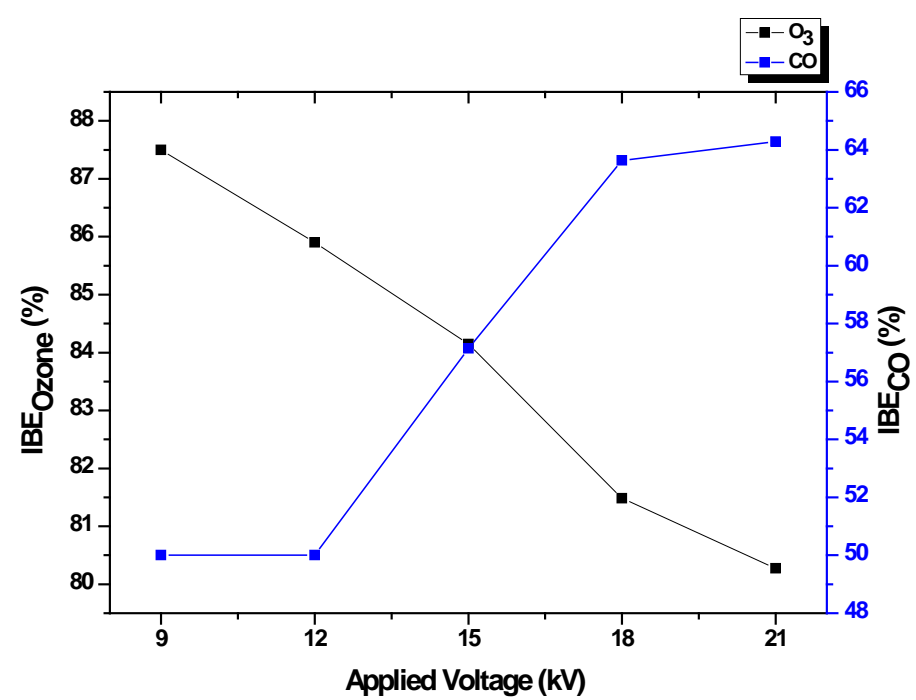

Fig.16. Variation the IBE of ozone and CO with applied voltage: $\left[\mathrm{CHCl}_{3}\right]=100 \mathrm{mg} \mathrm{m}^{-3}, \mathrm{Q}=2 \mathrm{~m}^{3} \mathrm{~h}^{-1}, \mathrm{RH}=90 \%, \mathrm{I}=20 \mathrm{~W} \mathrm{~m}^{-2}, \mathrm{~T}=20^{\circ} \mathrm{C}$.

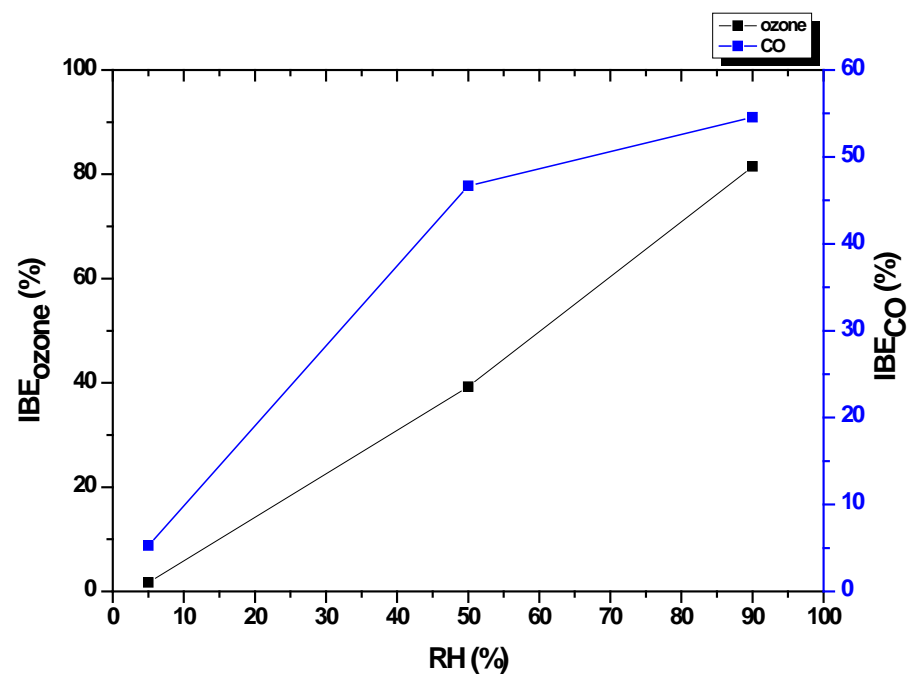

Fig.17. Variation the IBE of ozone and $\mathrm{CO}$ with $\mathrm{RH}$ :

$\left[\mathrm{CHCl}_{3}\right]=100 \mathrm{mg} \mathrm{m}^{-3}, \mathrm{Q}=2 \mathrm{~m}^{3} \mathrm{~h}^{-1}, \mathrm{~V}=18 \mathrm{kV}, \mathrm{l}=20 \mathrm{~W} \mathrm{~m}^{-2}, \mathrm{~T}=20^{\circ} \mathrm{C}$. 


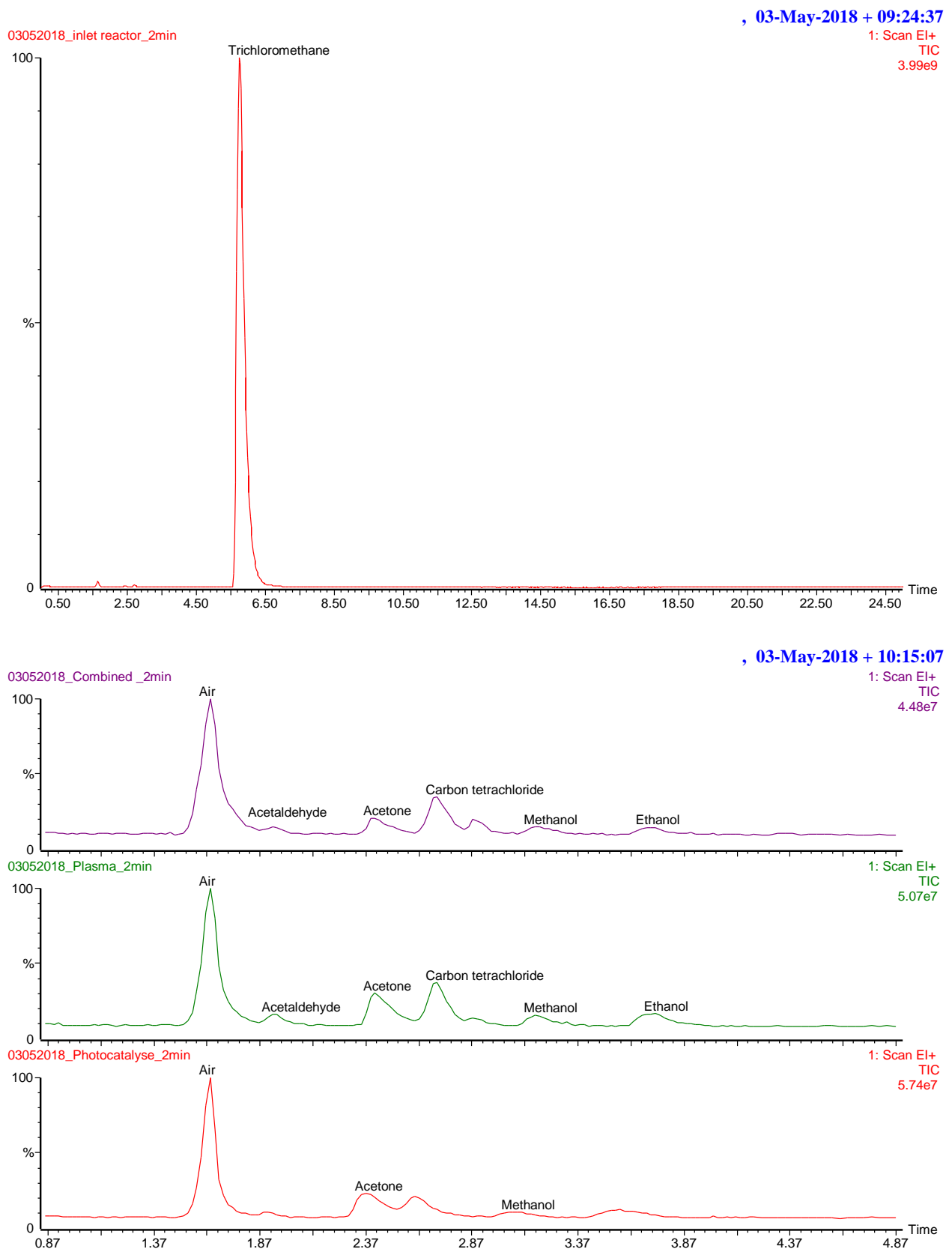

Figure 18. By-products identified by GC-MS following Trichloromethane oxidation by the different processes. Uapp $=15 \mathrm{kV},\left[\mathrm{CHCl}_{3}\right]_{0}=50 \mathrm{mg} \mathrm{m}^{-3}, \mathrm{Q}=2 \mathrm{~m}^{3} \mathrm{~h}^{-1}$ 